\title{
Mr. Hazim OKANOVIĆ
}

Fakultet za upravu pridružena članica Univerziteta u Sarajevu

E-mail: hazim.okanovic@fu.unsa.ba

Pregledni rad/Review article

UDK/UDC: 32:34(497.6)"1995/2021" (094)

327.7:341.1:342.5(497.6)"1995/2021"

DOI: https://doi.org/10.52259/historijskipogledi.2021.4.6.302

\section{ZNAČAJ NEVLADINIH ORGANIZACIJA U DONOŠENJU JAVNIH POLITIKA U BOSNI I HERCEGOVINI U VREMENU NAKON DEJTONSKOG SPORAZUMA}

\begin{abstract}
Abstrakt: Glavni cilj ovog rada je istraživanje mehanizama uticaja NVO-a na donošenje javnih politika u Bosni i Hercegovni nakon potpisivanja Dejtonskog mirovnog sporazuma 14. decembra 1995. u Parizu. Do naglog porasta broja nevladinih organizacija dešava se neposredno nakon Dejtonskog sporazuma, i prema nekim procjenama, tada ih je bilo više od 1.500, što ne može smatrati velikim brojem kada se poredi sa brojem NVO-a u drugim zemljama u tranziciji. Podaci Zbirnog registra fondacija i udruženja u Bosni $i$ Hercegovini navode kako je njihov ukupan broj je 25.646, dok je broj stvarno aktivnih teško utvrditi.

Dosadašnja literatura je pokazala da nevladin sektor u Bosni $i$ Hercegovini u značajnoj mjeri utiče na kreiranje javnih politika, ali su rezultati istraživanja $i$ ova tvrdnja prvenstveno doneseni na osnovu malog broja kvalitativnih primjera uticaja pojedinačnih nevladinih organizacija (case studies).

Ovaj istrazivački rad ima za cilj da sistematski istraži domen uticaja nevladinog sektora, kroz kvantitativnu analizu novoprikupljenih podataka o uticaju nevladinih organizacija. Anketno istraživanje je provedeno na lokalnom, kantonalnom, entitetskom te državnom nivou na reprezentativnom $i$ stratificiranom uzorku (10\% - prema statističkoj metodi) a obuhvatilo je rukovodioce $i$ aktiviste nevladinih organizacija, te službenike organa državne uprave (ministarstva i državne upravne organizacije).

Jedna od glavnih pretpostavki je da uspješnim umrežavanjem sa organizacijama iz susjednih zemljama članica Evropske unije, nevladine organizacije postaju respektabilan akter u donošenju javnih politika u Bosni $i$ Hercegovini. Pored kvantitativne analize, ovaj rad pruža detaljan pregled $i$ teorijsku analizu civilnog društva, nevladinog sektora $i$ javnih politika kao $i$ komparativni uvid $u$ institucionalne $i$ neinstitucionalne mehanizme uticaja
\end{abstract}


NVO-a na donošenje javnih politika u Bosni i Hercegovini, te njihovu praktičnu primjenu u zemljama iz okruženja i Evropske unije.

Ovaj rad doprinosi boljem razumijevanju uloge nevladinog sektora (udruženja) u javnom zagovaranju te analizi i kompariranju aktuelnih teorija pravno političkog okvira, strukture, veličine, faktora razvoja nevladinog sektora. Osim toga, rad doprinosi ocjeni trenutnog stanja mehanizma uticaja na kreiranje agendi javnih politika u Bosni i Hercegovini, formulisanja mjere za unutrašnje strukture $i$ umreženosti NVO-a te definisanje njihovog broja, strukture i tipova.

Problem istraživanja se ogleda u tome što započeti procesi transformacije i nedovršeni proces tranzicije bosanskohercegovačkog društva $i$ civilnog sektora su, usljed ratnih razaranja, značajno usporeni. Promjene u društvu u predratnoj fazi kreirale su realne pretpostavke za razvoj nevladinog sektora i općenito civilnog društva, i predstavljale realne osnove za uticaj na zagovaranje $i$ kreiranje različitih javnih politika. U postratnom periodu, međunarodni donatori su mnogo investirali u nevladin sektor.

Predmet ovog istraživanja je uticaj nevladinog sektora na procese donošenja javnih politika, kroz spoznaju o institucionalnim mehanizmima, kao $i$ korelacija nevladinog sektora $i$ javnih politika s aspekta razvoja demokratije kao integralnog procesa u svim njegovim aspektima.

$S$ obzirom kako je ova tematika prethodno djelimično obrađivana $u$ ovom kontekstu, kroz sistemski pregled problema i ponudu adekvatnog rješenja problema, neophodno je ponovo ispitati ključna pitanja. Ključna pitanja koja su istražena unutar ovog rada su kako umrežavanje sa susjednim zemljama članicama EU pozitivno utice (ima pozitivnu asocijaciju) na značaj koji nevladine organizacije imaju u zagovaranju javnih politika. Osim toga, istraženo je u kojoj mjeri finansijska potpora institucija Evropske unije pozitivno utiče na značaj koji nevladine organizacije imaju u zagovaranju javnih politika.

Ključne riječi: Nevladin sektor, javna politika, organi državne uprave, Bosna i Hercegovina, Evropska unija.

\title{
THE IMPORTANCE OF NON-GOVERNMENTAL ORGANIZATIONS IN PUBLIC POLICY-MAKING IN BOSNIA AND HERZEGOVINA IN THE TIME AFTER THE DAYTON AGREEMENT
}

\begin{abstract}
Summary: The main goal of this paper is to investigate the mechanisms of the influence of NGOs on public policy-making in Bosnia and Herzegovina after the signing of the Dayton Peace Agreement on December 14, 1995 in Paris. The sharp increase in the number of NGOs occurs immediately after the Dayton Accords, and according to some estimates, there were more than 1,500 at the time, which cannot be considered a large number when
\end{abstract}


compared to the number of NGOs in other transition countries. Data from the Collective Register of Foundations and Associations in Bosnia and Herzegovina state that their total number is 25,646, while the number of actually active is difficult to determine.

The literature so far has been presented from the non-governmental sector in Bosnia and Herzegovina to a significant extent for public policy making, as well as research results and these claims primarily based on the number of qualitative impact diaries of individual NGOs (case studies).

This research paper aims at systematic research of the domain of influence of the non-governmental sector, through quantitative analysis of newly collected data on the influence of non-governmental organizations. The survey was proven at the local, cantonal, authorial and state level on a representative and stratified sample (10\% - according to the statistical method) and was trained by the leadership and activists of non-governmental organizations and government officials (ministries and state administrative organizations).

One of the main assumptions is that by successfully networking with organizations from neighboring EU member states, NGOs become a respectable actor in public policy-making in Bosnia and Herzegovina. In addition to quantitative analysis, this paper provides a detailed overview and theoretical analysis of civil society, NGO sector and public policies as well as a comparative insight into institutional and non-institutional mechanisms of NGO influence on public policy making in Bosnia and Herzegovina and their practical application in neighboring countries European Union.

This paper contributes to a better understanding of the role of the non-governmental sector (association) in public advocacy and the analysis and comparison of current theories of the legal policy framework, structure, size, factors of development of the non-governmental sector. In addition, the paper contributes to the assessment of the current state of the mechanism of influence on the creation of public policy agendas in Bosnia and Herzegovina, the formulation of measures for internal structures and networking of NGOs and the definition of their number, structure and types.

The problem of the research is reflected in the fact that the started processes of transformation and the unfinished process of transition of the Bosnian society and civil sector are, due to the war destructions, significantly slowed down. Changes in society in the pre-war phase created realistic preconditions for the development of the non-governmental sector and civil society in general, and provided a realistic basis for influencing the advocacy and creation of various public policies. In the post-war period, international donors invested heavily in the NGO sector.

The subject of this research is the influence of the non-governmental sector on policy-making processes, through knowledge of institutional mechanisms, as well as the correlation of the non-governmental sector and 
public policies from the aspect of democracy development as an integral process in all its aspects.

Given that this topic has previously been partially addressed in this context, through a systematic review of the problem and offering an adequate solution to the problem, it is necessary to re-examine the key issues. The key issues explored within this paper are how networking with neighboring $E U$ Member States has a positive impact (has a positive association) on the importance of $N G O s$ in advocating for public policies. In addition, the extent to which financial support from EU institutions has a positive impact on the importance of NGOs in advocating for public policies has been explored.

Key words: Non-governmental sector, public policy, state administration bodies, Bosnia and Herzegovina, European Union.

\section{Uvod: pregled trećeg sektora u svijetu i Bosni i Hercegovini}

Organizacije civilnog društva imaju važnu ulogu podsrednika između javnih vlasti i građana. Nevladine organizacije se generalno govoreći, smatraju pokretačkom snagom i ključnim segmentom civilnog društva posebno u zemljama $\mathrm{u}$ razvoju, $\mathrm{u}$ tranziciji, u začecima demokratije. ${ }^{1}$ Nevladine organizacije pripadaju skupini organizacija civilnog društva, trećeg sektora, osnovane sa ciljem da rješavaju probleme sa kojima se susreće njihova zajednica. U svijetu treći sektor je poznat kao neprofitni sektor (non-profit sector) dok se u Velikoj Britaniji naziva volonterskim sektorom (voluntary and community sector). "U Francuskoj se koristi socijalna ekonomija (economie sociale) dok se u većini centralnih i jugoistočnih evropskih država naziva nevladinim sektorom. Najznačajnije aktivnosti trećeg sektora su pripisivane javnom ili privatnom sektoru. Analiza javnih politika započinje svoj razvoj krajem šezdesetih godina proštog vijeka dok je danas jedna od standardnih poddisciplina političkih nauka. Njezini se izvori i poticaji nalaze u politologiji i srodnim društvenim naukama". ${ }^{2}$ Osnove javnih politika su nastale unutar teorija sistema i one su ,izlazna strana“ političkog sistema unutar kojeg se odvija autonomna lokacija vrijednosti za cjelokupno društvo. Đorđević navodi zanimljiva poimanja policyja kako u razmatranju užeg tako i šireg plana. "Prva teorija je nastala unutar teorija sistema gdje se javne politike javljaju kao proizvodi odnosno kao rezultati ishoda političkog sistema. Drugo gledište pojma policy kao opće smjernice koje vlasti nastoje poduzeti gdje se konkretne odluke uvijek razmatraju kao dio širokog plana. Treće poimanje koje predstavlja možda i najutjecajniji pristup koji policy promatra kao djelovanje

${ }^{1}$ Đorđe Stojanović, Građansko društvo, Medijska knjižara krug, Beograd 2006, 255.

${ }^{2}$ Grancis G. Castles, Komparativne javne politike-primjeri poslijeratne preobrazbe, Masmedija, Zagreb 2009, 40. 
koje je orijentirano na ostvarenje kratkoročnih ili dugoročnih ciljeva i općenito, svih drugih svrha i namjera. Polazna faza u kreiranju javne politike sastoji se od identifikacije određenog problema koji postoji u zajednici. Koji problem riješiti zahtijeva informacije o prethodnim uslovima problema, kao i informacije o vrijednostima čije ostvarenje može dovesti do ostvarenja problema. Informacije o policy problemima igraju ključnu ulogu u analizi javnih politika. Postoji nekoliko tipova javnih politika i to: distributivna, redistributivna, regulativna, većinska itd." 3

"U Sjedinjenim Američkim Državama kao zemlji sa najrazvijenijom tradicijom dobrovoljnog organizovanja, pravni status neprofitnih organizacija (non for profit) je urađen kroz zakone o oporezivanju dohotka koji potiču još od početka 20. stoljeća. Ne postoji nikakva pravna norma koja reguliše djelatnost organizacije, što pojednostavljuje registraciju nevladinih organizacija osnivači su „slobodni da vlastitim riječima opišu ono što žele da rade".4 "Razlikuju se tri mehanizma i načina uticaja nevladinih organizacija na kreiranje javnih politika u Sjedinjenim Američkim Državama i to: a) javno zagovaranje, na primjer volonteri nevladinog sektora su među prvima javno, putem demonstracija zagovarali prestanak kršenja ljudskih i građanskih prava što je za rezultat imalo ukidanje rasističkih zakona u južnim dijelovima SAD-a, polovinom 20. vijeka; b) građanski savjetodavni komiteti, komisija matila i javne rasprave gdje nevladine organizacije, i zvanični kreatori javnih politika postižu konsenzus o bitnim pitanjima zajednice i društva u cjelini i lokalne (komunalne) radionice i otvoreni forumi u čijem radu obično učestvuju svi članovi jedne zajednice, vladine agencije, nevladine organizacije javne institucije kojih se tiče neko pitanje ili problem. Pravo na slobodu mirnog okupljanja i udruživanja, garantovano je Općom deklaracijom Ujedinjenih nacija o ljudskim pravima i Evropskom konvencijom za zaštitu ljudskih prava i osnovnih sloboda". ${ }^{5}$ Primjeri iz svijeta navedeni u prvom dijelu rada pokazuju Primjeri pokazuju kako se policy može razmatrati kroz uži i širi plan dok se faze kreiranja javnih politika sastoji od identifikacije problema koji postoji u zajednici. Osim toga, ocijenjeno je kako informacije o policy problemima igraju ključnu ulogu u analizi javnih politika kao i u mehanizmima i načinima uticaja na njih što je od izuzetne važnost i za usporedbu sa primjerima u Bosni i Hercegovini. "Pravni okvir za osnivanje i djelovanje nevladinih organizacija u Bosni i Hercegovini sadržan je u Ustavu Bosne i Hercegovine, koji omogućava da sva lica na teritoriji Bosne i Hercegovine uživaju ljudska prava i slobode sadržane u Evropskoj konvenciji za zaštitu ljudskih prava i osnovnih sloboda, između ostalog i pravo na slobodu mirnog okupljanja i slobodu udruživanja sa drugima. Prema analizi strukture rada nevladinih organizacija koje je proveo

\footnotetext{
${ }^{3}$ Snježana Đorđević, Analiza javnih politika, Čigoja, Beograd 2010, 283.

${ }^{4}$ Branko Petrović et al, Civilno društvo i nevladin sektor, Magna Agenda, Beograd 2002.

5 Zvonimir Mataga, Pravno na slobodu udruživanja prema Evropskoj konvenciji za zaštitu ljudskih prava i osnovnih sloboda, Strazbur 2006, 5.
} 
CPCD, prema sadržaju i oblastima one se dijele na one koje se bave: obrazovanjem i istraživanjem, socijalnim i humanitarnim uslugama, mladima, razvoju lokalne zajednice, genderom, zastupanjem i drugo. Civilno društvo znači „udruživanje“, „općinu“, „zajednicu“ građana kao politički uticaj zajednicu, odnosno najviši oblik udruživanja slobodnih građana u cilju zajedničkog odlučivanja o društvenim problemima i prioritetima. Građansko društvo izjednačeno je sa političkom zajednicom ali je pojmovno suprostavljeno kući, odnosno kućnom društvu. Leonardo Bruni prvi je upotrijebio izraz societas civilis kao latinski izraz za grčki koinonia politike". ${ }^{6}$ "Raznovrsne su organizacije grupisane pod krovnim pojmovima kao što su „nevladine organizacije“, „,neprofitna organizacija“ organizacije“, 'organizacije civilnog društva' ili 'treći sektor”.? "One se mogu zvati „NVO-ima društvene svrhe“, kao što su ekološke grupe, organizacije za ljudska prava, organizacije koje se bore protiv siromaštva i u fazi su razvoja ili pružaju medicinsku pomoć u hitnim slučajevima". 8 "Civilno-političke nevladine organizacije izražavaju forme i alternativne politike članova drustva koji su nedovoljno zastupljeni u zvaničnoj političkoj sferi. Neke od ovih organizacija imaju članove koji su na visokom položaju i koji su bili aktivni u građanskim inicijativama tokom 1980-ih u Bosni i Hercegovini, ali su sve nastale kao odgovor da ospore pretpostavke po kojima su glavne nacionalistički orijentisane partije djelovale tokom $\mathrm{i}$ poslije rata $\mathrm{i}$, posebno, da ospore pretpostavku dominacije nacionalnoetničkih principa kao što je zajamčeno Daytonskim ustavom". "S obzirom na uticajnu ulogu međunarodne zajednice i međunarodnih donatora na iniciranje i razvoj sektora, NVO se češće percipiraju kao produžena ruka međunarodnih organizacija, negoli kao okosnica civilnog društva. Iako je ovo dominant gledište, bitno je naglasiti da predstavnici lokalnih NVO nisu lobirali ili davali komentare donatorima koje potrebe i interesi građana nisu obuhvaćeni donatorskim misijama, ciljevima i zadacima". ${ }^{10}$

\footnotetext{
${ }^{6}$ Vukašin Pavlović, Civilno društvo i demokratija, Udruženje za političke nauka, Srbije, Beograd 2004, 18-19, (dalje: V. Pavlović, Civilno društvo i demokratija).

${ }^{7}$ Hildy Teegen, et al. The importance of nongovernmental organizations (NGOs) in global governance and value creation: An international business research agenda, Journal od International Business Studies, 2004, vol. 35, 463-483.

${ }^{8}$ Alnoor Ebrahim, World Development, vol. 31, issue 5, 2003, 813-829.

${ }^{9}$ Paul Stubbs i Kendra Gregson, (urednici): Social Policy, Protection and Practice: the care of vulnerable groups in Bosnia-Herzegovina, Svijetlost, Sarajevo 1998, 24.

${ }^{10}$ Reima Ana Maglajlić, Edin Hodžić, "Political Participation." In Democracy Assessment in Bosnia and Herzegovina, ed. Dobrila Govedarica, Open Society Fund Bosnia and Herzegovina, Sarajevo 2006, 30.
} 


\section{Pregled literature i teorijski okvir}

"Civilno društvo može se definirati kao složeno i dinamičko društvo s kojem su zakonom zaštićene autonomija i sloboda nevladiniih institucija, koje su na jednoj strani orijentisani na nenasilje, samorganizaciju i samorefleksiju i na drugoj strani, egzistiraju permanentno pod tenzijom u međusobnim korelacijama i u svojim odnosima sa državnim institucijama koje oblikuju, limitiraju i u krajnjem, omogućavaju ove aktivnosti". ${ }^{11}$ Po Antonu Gramšiju civilno "društvo je konstituisano od dvije vrste elemenata: kulturno-vrijednosnih sadržaja s jedne, kao i mreža institucija i građanskih asocijacija sa druge strane. On gleda na civilno društvo kao na najvažniji društveni teren u kom se vodi „,rovovska borba za novi poredak". ${ }^{12}$ "Nevladin sektor predstavlja „terminološku raznolikost u zavisnosti od političkog, kulturnog i privrednog razvoja, neprofitni sektor se različito naziva u različitim zemljama. Neprofitni sektor termin koji se najčešće prihvata, naglašava da ove organizacije, za raziiku od profitnih, ne postoje primarno radi ostvarivanja protita". ${ }^{13}$

Pod javnim zagovaranjem (engl. advocacy) podrazumijeva intervenciju u stvarnosti radi uvođenja neke promjene i to ukorist onih koji nemaju moć ili je imaju nedovoljno. "Javno zagovaranje ima tri bitna elementa i to: a) uvijek ima svoju ciljnu publiku a to su kreatori politika (oni donosioci odluka koji imaju autoritet i ovlaštenje da utiču na zadatak javnog zagovaranja), b) zadatak (promjena ustava, zakona, promjena politike, prakse itd) i c) indikatore uspjeha (usvajanje novog ili povoljnijeg programa, primjena određenog zakona ili prakse itd). Javne politike (policy) u najkraćem mogu se razumijeti kao praktična (konkretna) politika na djelu. Endrju Hejvud pod javnom politikom podrazumijeva "formalne, odnosno formulirane odluke vladinih tijela“. ${ }^{14}$ Gaj Peters “javnom politikom” smatra ,zbroj vladinih aktivnosti koje imaju utjecaj na život građana“. ${ }^{15}$ Državna uprava predstavlja skup državnih organa i pravnih propisa koji su namjenski osnovani ili donešeni od države s ciljem upravne regulacije svih važnijih društvenih odnosa. Kako navodi Jovanović pod pojmom uprave se najčešće podrazumijeva državna uprava i ona se shvata najčešće u organizaciono-formalnom smislu." Uprava se definiše kao državna djelatnost koju vrše državni organi uprave prema ustavu i zakonima države. "I to je u skladu sa načelom podjele vlasti na: zakonodavnu, upravnu i sudsku". "Pojam javna uprava je širi pojam od državne uprave, jer označava sve vršioce upravne djelatnosti, kako u okviru državne organizacione strukture (upravne organe i

\footnotetext{
${ }^{11}$ Džin Kin, Civilno društvo, stare slike, nove vizije, Filip Višnjić, Beograd 2003, 243.

${ }_{12}$ V. Pavlović, Civilno društvo i demokratija, 50.

${ }^{13}$ Marija Kolin, Nevladine organizacije (pojam, značaj, klasifikacije, profil), u: B. Petrović [ur] Civilno društvo i nevladin sektor, Palgo centar, Beograd 2002, 66.

${ }^{14}$ Frances Heywood, Understanding needs: A starting point for quality, Housing Studies, 19(5), 2004, 709-726.

15 Gay Peters, Jon Pierre, (ur), Handbook of Public Policy, Sage, London 2004, 461-479.

16 Slobodan Jovanović, Država I, Geca Kon, Beograd 1936, 223.
} 
druge državne organe koji su ovlašćeni za vršenje upravnih aktivnosti), tako i izvan nje (nedržavne subjekte sa javnim ovlaštenjima), a ne samo državne organe uprave kao vršioce upravnih aktivnosti". ${ }^{17}$ Dosadašnja literatura je pokazala da nevladin sektor $u$ Bosni i Hercegovini društvu u značajnoj mjeri utiče na kreiranje javnih politika, ali su rezultati istrazivanja i ova tvrdnja prvenstveno doneseni na osnovu malog broja kvalitativnih primjera uticaja pojedinačnih (samo nekih od) nevladinih organizacija (case studies). Ovaj istraživački rad ima za cilj da sistematski istraži domen uticaja nevladinog sektora, kroz kvantitativnu analizu novoprikupljenih podataka o uticaju nevladinih organizacija. Od urušavanja socijalističkog sistema koji se na simboličkoj ravni manifestirao padom Berlinskog zida i pojavom organizacija civilnog društva i savremenih nevladinih organizacija kao njihovog značajnijeg dijela u Bosni i Hercegovini, ovo polje, je u velikoj mjeri neistraženo te ne postoji niti jedna kompleksna $\mathrm{i}$ ozbiljna sistemska naučna analiza iz domena uticaja nevladinog sektora na kreiranje javnih politika, niti analiza koja se bavi uticajem civilnog društva na kreiranje javnih politika. Period od pojave savremenih nevladinih organizacija do danas sasvim je dovoljan vremenski period za naučno posmatranje njihovog uticaja na kreiranje javnih politika u Bosni i Hercegovini.

Ukoliko se pri tome doda kako je problem postao još više aktuelan približavanjem bosansko-hercegovačkog društva demokratskim standardima u Evropsku uniju, onda se dobija dodatni motiv za istraživanje ovog fenomena. Ograničenja u ovom kompleksnom poslu su nam predstavljali ključni termini: javna politika i nevladin sektor, koji nemaju dugu tradiciju i u Bosni i Hercegovini su različito tumačeni i prevođeni u naučnim i stručnim krugovima. Unutar ovog rada analiziran je razvoj civilnog društva i nevladinih organizacija u Bosni i Hercegovini i njihovom uticaju na kreiranje cjelokupnog ciklusa javne politike. U tom smislu prisutna je komparativna analiza razvoja civilnog društva i nevladinih organizacija u državama iz okruženja Bosne i Hercegovine (te zemlje Zapadnog Balkana), kao i mehanizmi uticaja na kreiranje javnih politika. Predmet ovog istraživanja je uticaj nevladinog sektora na procese donošenja javnih politika, kroz spoznaju o institucionalnim mehanizmima, kao i korelacija nevladinog sektora $i$ javnih politika $s$ aspekta razvoja demokratije kao integralnog procesa u svim njegovim aspektima. "Udruženja građana, neprofitne organizacije ili političke stranke mogu se razumjeti kao izraz građanskog društva, ali i društvene vrijednosti, javno mnijenje ili demokratije". ${ }^{18}$

"Nevladine organizacije koje nose i naziv 'treći sektor', ne učestvuju u vladanju niti imaju političke ambicije, osnovali su ih fizička ili pravna lica i područje njihovog djelovanja je vrlo široko. U slučaju dovoljno razvijenog civilnog društva, postoje nevladine organizacije koje pokrivaju sve građanske

\footnotetext{
17 Stevan Lilić, Upravno pravo, Upravno procesno pravo, Beograd 2008, 41.

18 Edward N. Muller, Mitchell A. Seligson, Civic culture and democracy: the question of causal relations, American Political Science Review, vol. 88, no. 3, 1994.
} 
interese i potrebe". ${ }^{19}$ "U široj definiciji, međunarodne nevladine organizacije (NVO) su privatne neprofitne institucije koje djeluju sa krajnjim ciljem poboljšanja društva". ${ }^{20}$ "NVO se identifikuje kao nezavisno dobrovoljno udruženje građana koji djeluju zajedno na kontinuiranoj osnovi, radi ostvarenja zajedničkog cilja, koji nije dolazak na vlast, zarada novca ili pravno nedozvoljene aktivnosti". ${ }^{21}$

"Nakon 1995. godine i potpisivanja Opšteg okvirnog sporazuma za mir u Bosni i Hercegovini, kojim je okončan rat u Bosni i Hercegovini, došlo je do naglog porasta broja nevladinih organizacija, i prema nekim procjenama, tada ih je bilo više od 1.500, što se ipak ne može smatrati velikim brojem kada se poredi sa brojem NVO-a u drugim zemljama u tranziciji. Razlikovanje pojavnih oblika NVO-a u dva bosanskohercegovačka entiteta, Federaciji Bosne i Hercegovine (FBiH) i Republici Srpskoj (RS), može nas uvesti u ranije više prisutnu neusklađenost relevantnog entitetskog zakonodavstva za nevladine organizacije". ${ }^{22}$ Građansko pravo na udruživanje je, ustvari, postalo jednim od temelja slobodnog demokratskog društva i pravno - političkog sistema (države). U tom kontekstu se permanentno zagovara aktivno učešće svih članova društvene zajednice kroz razne asocijacije, udruženja i institucije s ciljem promoviranja pojedinačnih i kolektivnih prava i interesa svih članova društva. Koristeći se pravom na udruživanje, građani imaju mogućnost svoje pojedinačne interese i ciljeve podići na viši nivo, o njima javno diskutirati, mijenjati ih ili eventualno prilagođavati interesima udruženja ili asocijacije kojoj pripada. Time povećavaju svoje šanse i mogućnosti da, kroz realizirane kolektivne ciljeve, ostvari u značajnom dijelu i svoje individualne ciljeve i interese. Ohrabrivanje građanskog učešća od velikog je značanje posebno uzme li se u obzir demokratske inovacije koje su fokusirane na efikasno uključivanje građana. Građanske inicijative, društveni pokreti su dio učešća građana odnosno civilnog društva u demokratskom društvu. Znatan je broj socijalno isključenih kategorija građana relativno niska razina obrazovanja, samopouzdanja i motivacije, prisutni zdravstveni problemi i nedostatak radnog iskustva. U skladu s tim, potrebno ih je ohrabrivati i uključivati u programe obrazovanja odraslih s ciljem sticanja potrebnih znanja i vještina te jačati individualizirani pristup usluga mentora. Ostavlja se opravdanim pitanje koji su to pravni i strateški okviri, koje javne politike i prakse se primjenjuju u borbi protiv socijalne isključenosti?

\footnotetext{
${ }^{19}$ Quentin Kidd, Civic Participation in America, Springer, New York 2016, 195.

${ }^{20}$ David Lewis, (eds). Pluto: London, Sheelagh Stewart 1997, 1-36. Happy ever after in the marketplace: non-government organizations and uncivil society. Review of African Political Economy, No. 71, 11-34.

${ }^{21}$ Peter Willetts, What is a Non-Governmental Organization? In UNESCO (Eds), Encyclopedia of Life Support Systems: Encyclopedia of Institutional and Infrastructural Resources, Eolss Publishers, Oxford 2002, 5.

22 Sevima Sali Terzić, Civilno društvo, Poglavlje XI u Međunarodne političke podrške zemljama jugoistočne Evrope - Lekcije (ne)naučene u Bosni i Hercegovini, Fond otvoreno društvo ViH, Sarajevo 2001, 177.
} 
Participacija nevladinih organizacija kreće se od aktivnog uključivanja u javne rasprave na poziv organizatora do partnerstva sa vladinim organizacijama $i, u$ nekoliko slučajeva, organizatora. Mnoštvo je faktora koji utiču na odluke svakog pojedinačnog građanina na to da li će se uključiti u proces javnih konsultacija. Uglavnom se tiču motivacije. Radnosposobne osobe moraju sistemski raditi na poboljšanju svoje motiviranosti za zapošljavanje i jačanju ljudskog kapitala, znanja, stručnosti i sposobnosti, kao i zdravstvenog stanja, kako bi unaprijedile svoju zapošljivost i postale zanimljive mogućim poslodavcima. Ne može se očekivati da će ljudi biti podjednako uporni u sticanju novih znanja i sposobnosti ili u preuzimanju rizika, ali je presudno da se društvenom aktivnošću svima omogući približno sličan startni položaj u životu. To se može postići pomoću programa poticanja školovanja i većeg javnog ulaganja u obrazovanje najsiromašnijih skupina, boljim i podjednakim pristupom javnim uslugama i informacijama te jednakošću u poštivanju prava, obaveza i odgovornosti. Javne politike su oblik društvene konstrukcije usmjerene na rješavanje problema s kojima se suočava neka politička zajednica, i one se ne vezuje isključivo uz djelovanje vlade. Javne politike, ustvari, predstavljaju konkretne (praktične) politike usmjerene na rješavanje aktualnih pitanja i problema koji opterećavaju određeno društvo, društvenu zajednicu, državu. Suština javne politike je konkretnost, odnosno praktična (politička) djelatnost i aktivnost. U biti postoje jasni i odgovarajući programi, strategije, planovi ili projekti koje javna vlast implementiranjem određenih politika i mjera nastoji realizirati na dobrobit zajednice. Ti programi, strategije i planovi su, ustvari, dokumenti koji detektiraju pojedine ili većinu političkih praktičnih problema, te nude mehanizme i mjere najboljeg pristupa rješenju promatranih i analiziranih problema.

"Savremena klasifikacija javnih politika se temelji na tri važna aspekta, a to su sljedeći aspekti: 1) područje djelovanja; 2) ciljne skupine i 3 ) institucionalni okvir". ${ }^{23}$ Povezivanje nevladinih organizacija s okruženjem Evropske unije znači veću inozemnu potporu, koja predstavlja temeljni podsticaj razvoju ovih organizacija. U sklopu istraživanja unutar ovog članka, uzet će se u obzir i case studiyje na primjeru zemalja Mađarske i Hrvatske jer se u njima nalazi značajan broj nevladinih organizacija koje se bave ostvarivanjem mjera javnih politikama koje će se nakon analize komparirati sa onim u Bosni i Hercegovini. Evropska nija je teritorijalno najbliža Bosni i Hercegovini i nalazi se u istom geografskom predjelu. Evropska unija ima veliki uticaj na različite aspekte političkog i javnog života u Bosni i Hercegovini. Institucionalne metode uticaja nevladinih organizacija su: javno zagovaranje, monitoring, politička participacija, kontrola tajnog u politici i edukacija. Ipak, najznačajnije su institucionalne metode utjecaja nevladinih organizacija na kreiranje javnih politika prisutnih u praksi

\footnotetext{
${ }^{23}$ Ermin Kuka, Javne politike, Štamparija Fojnica d.o.o, Sarajevo 2018, 56. (dalje: E. Kuka: Javne politike)
} 
bosanskohercegovačkog nevladinog sektora. Dvadeseto stoljeće dalo je doprinos sa tri značajne teorijske inovacije: gramšijevo shvatanje civilnog društva, zatim doprinos teoretičara novih društvenih pokreta i najzad Habermansovo istraživanje javnog mnijenja. „Terminološka raznolikost u zavisnosti od političkog, kulturnog i privrednog razvoja, neprofitni sektor se različito naziva u različitim zemljama. U Sjedinjenim Američkim Državama je poznat kao neprofitni sektor (non-profit sector), u Velikoj Britaniji se naziva volonterskim sektorom (volunteer sector) dok je u Francuskoj socijalna ekonomija (economie sociale). U većini centralnih i jugo-istočnih evropskih zemalja, naziva se nevladin sektor. Neprofitni sektor termin koji se najčešće prihvata, naglašava da ove organizacije, za raziiku od profitnih, ne postoje primarno radi ostvarivanja protita". 24 "Može se konstatovati kako su se NVO pojavile kao važni globalni akteri u posljednjih nekoliko godina te da su pokušali stupiti u kontakt sa moćnima institucijama, što se uglavnom odnosi na društvenu svrhu nevladine organizacije koje se bave kvalitetom života u cjelin zajednice čiji je cilj promocija društvenih promjena. Ukoliko su poslovne organizacije jedna od dominantne institucije u globaliziranom svijetu, NVO su uzeli ih kao mete svojih akcija". ${ }^{25}$ "Da bi unaprijedili svoje interese, druge zainteresirane strane poput NVO uspostavljaju različite tipove odnosa s firmama: od kolaborativne do konfrontacionih akcija, kao što su protesti, bojkoti i građanske parnice. Od ignorisanja ili omalovažavanje ovih radnji može imati posljedice, postoje snažni poticaji za firme da promijene svoje politike koje udovoljavaju zahtjevima ovih stakeholder". ${ }^{26}$

"Nevladine organizacije uglavnom su neprofitne organizacije koje dobijaju barem dio svojih prihoda od privatnih donatora. Uobičajene aktivnosti uključuju, između ostalog: pružanje pomoći u vanrednim situacijama, poticanje ekonomskog razvoja za ublažavanje siromaštva i / ili zagovaranje građana sa nepovoljnim statusom/položajem". ${ }^{27}$ "Međunarodna klasifikacija neprofitnih organizacija (ICNPO) identifikuje 12 grupa organizacija a služe za prikupljanje podataka o veličini neprofitnog sektora u različitim zemljama i to: 1) Kultura i rekreacija; 2) Obrazovanje i istraživanje; 3) Zdravlje; 4. Socijalna zaštita; 5) Zaštita životne sredine; 6) Razvoj i stanovanje; 7) Građanska prava i zastupanje; 8) Filantropija i promocija dobrovoljnog rada; 9) Međunarodne organizacije; 10) Preduzeća, profesionalne organizacije, udruženja; 11) Vjerske organizacije i 12)

\footnotetext{
${ }^{24}$ Marija Kolin, Nevladine organizacije (pojam, značaj, klasifikacije, profil). u: Branko Petrović [ur] Civilno društvo i nevladin sektor, Palgo centar, Beograd 2002.

25 Jamie R. Hendry, Taking Aim at Business: What Factors Lead Enviromental Non-Governmental Organizations to Target Particular Firms), Bussiness Society, 2006, 45, 47.

${ }^{26}$ Charles Eesley \& Michael J. Lenox, "Secondary Stakeholder Actions and the Selection of Firm Targets," Working Paper. Also, Best Paper Proceedings of the 2006 Academy of Management Conference. Atlanta, GA. August, 2006.

${ }^{27}$ Lester M. Salamon, et al, Defining the Nonprofit Sector: A Cross - National Analysis, Manchester University Press, Manchester 2004, 128-168.
} 
Ostale organizacije". ${ }^{28}$ "U najkraćem, javna politika (policy) bi se mogla razumijeti kao praktična (konkretna) politika na djelu". ${ }^{29}$ "Glavni akteri stvaranja javnih politika su vlade, a zatim slijede i svi ostali društveni akteri na koje određena javna politika može imati direktan ili indirektan uticaj (nevladine organizacije, skupine, pojedinci...)". ${ }^{30}$ "U državama sa razvijenom parlamentarnom (izbornom) demokratijom, nevladine organizacije imaju značajnu poziciju i utjecaj na stvaranje mnogih državnih javnih politika." "31 "U nezvanične (neformalne, neslužbene) aktere procesa stvaranja javnih politika se ubrajaju: interesne skupine, političke stranke, znanstvenici, stručnjaci, savjetnici, policy-analitičari, mediji, nevladine organizacije, udruge, istraživačke organizacije (eng. think tank), individualni građani, a u novije doba i određeni međunarodni akteri." ${ }^{32}$ Zainteresirani dionici mogu uključivati nevladine organizacije, međunarodne vladine organizacije, druge savjetnike ili centre za javne politike, lokalne vlasti, političke stranke, udruge, sindikate ili zainteresirane građane". ${ }^{33}$ Nevladine organizacije su legitiman i respektabilan akter u konsultativnom procesu donošenja i konačnog implementiranja javnih politika u Bosni i Hercegovini. "Pored javne vlasti, implementiranjem javnih politika se bave i druge skupine i organizacije (npr. razne nevladine organizacije, formalne i neformalne udruge građana, pa čak i sami pojedinci". ${ }^{34}$ Pored toga, značajan su akter u povezivanju s okruženjem Evropske unije što im daje posebno mjesto i ulogu. Pojava nevladinih organizacija i evolucija pojma javna politika trenutno je u centru interesovanja javnosti. Razvoj civilnog društva i nevladine organizacije u Bosni i Hercegovini imale su značajan uticaj na kreiranje agendi javnih politika i cjelokupnog ciklusa javne politike. Javne politike i nevladin sektor nemaju dugu tradiciju jer im kako politički tako i ekonomski sistem bivše Jugoslavije kao i Bosne i Hercegovine tokom socijalističkog perioda, nisu omogućavali razvoj. Nevladine organizacije u Bosni i Hercegovini nisu bile aktivne kao one u državama Zapadne Evrope ili Sjedinjenim Američkim Državama te su različito tumačene u naučnim i stručnim krugovima. Kako bi se istražio uticaj nevladinih organizacija na formiranje javnih politika važno je napraviti uvid u promjene u državama Istočne Evrope. Najprije devedesetih godina XX stoljeća dolazi do urušavanja Jugoslavije te međunarodnog priznavanja Bosne i Hercegovine.

\footnotetext{
${ }^{28}$ Marija Kolin, Nevladine organizacije (pojam, značaj, klasifikacije, profil), u: Branko Petrović [ur] Civilno društvo i nevladin sektor, Palgo centar, Beograd 2002.

${ }^{29}$ Emir Tahirović, Ermin Kuka, Osnove javnih politika, Fakultet za upravu Univerzitea u Sarajevu, Sarajevo 2020, 16. (dalje: E. Tahirović, E. Kuka, Osnove javnih politika).

${ }^{30}$ E. Tahirović, E. Kuka, Osnove javnih politika, 80.

31 Isto, 130.

32 Isto, 134.

${ }^{33}$ Eoin Young \& Quinn Lisa, Pisanje djelotvornih prijedloga za javne politike - Vodič za policy savjetnike u zemljama Središnje i Jugoistočne Europe, DIM - Udruga za građansko obrazovanje i društveni razvoj, Zagreb 2007, 15.

${ }^{34}$ E. Tahirović, E. Kuka, Osnove javnih politika, 51.
} 
Proces transformacije bosanskohercegovačkog civilnog sektora značajno je usporen tokom ratnih dešavanja tako da su sve aktivnosti bile zaustavljene. Tokom promjena u društvu u predratnoj fazi kreirane su realne pretpostavke za razvoj nevladinih organizacija kao i općenito civilnog društva. U tom periodu, javljaju se i realne osnove za uticaj na javnu politiku. Ipak, tokom ratnih dešavanja od 1992. do 1995. godine, dolazi do radikalnih promjena. Prije svega, dolazi do pojave nevladinih organizacija koje ne promovišu temeljne vrijednosti civilnog društva. Zbog ratnih dešavanja, nevladin sektor svoj fokus je usmjerio ka pomoći ili nadopuni javnih službi na pružanju i distribuiranju humanitarne pomoći. U postratnom periodu međunarodni donatori su mnogo investirali u nevladin sektor. Međunarodni donatori postaju neizostavni faktor funkcionisanja, rada i na kraju uticaja nevladinih organizacija. Istraživanje unutar ovog članka ima interdisciplinarni karakter (jer je u okviru više srodnih nauka kao što su uprava, političke nauke, pravo). Problem istraživanja se ogleda $\mathrm{u}$ tome što započeti procesi transformacije i nedovršeni proces tranzicije bosanskohercegovačkog društva i civilnog sektora su, usljed ratnih razaranja, značajno usporeni. Promjene u društvu u predratnoj fazi kreirale su realne pretpostavke za razvoj nevladinog sektora i općenito civilnog društva, i predstavljale realne osnove za uticaj na zagovaranje i kreiranje različitih javnih politika. U postratnom periodu, međunarodni donatori su mnogo investirali u nevladin sektor. Iako se posljednjih godina afirmira značaj nevladinih organizacija, još uvijek ne postoji pozitivna podrška ovakvim inicijativama, pa su rijetki primjeri uspješnog djelovanja tih organizacija u Bosni i Hercegovini i praktično su zasnovani isključivo na angažmanu visoko motiviranih pojedinaca. Povezivanje nevladinih organizacija s okruženjem Evropske unije znači veću inozemnu potporu, koja predstavlja temeljni podsticaj razvoju ovih organizacija. Neizostavan element u procesu promicanja javnih politika prava je saradnja nevladinih organizacija $\mathrm{s}$ nadležnim državnim tijelima (državnim akterima). "Akteri procesa kreiranja javnih politika su sve one individue, organizacije, ustanove i institucije (vladine i nevladine) na koje se direktno ili indirektno odnose određene javne politike koje se kreiraju i implementiraju". ${ }^{35}$ To nameće potrebu iniciranja adekvatnih i sveobuhvatnih koordinacijskih procesa s jasnim načinom, okvirom i mehanizmom zajedničkog rada i djelovanja radi poboljšanja i jačanja partnerskih odnosa, tako da se dolazi do zaključka kako je istraživanje unutar ovog rada iznimno aktuelno. Javno zagovaranje, kao društveni fazni proces, usmjereno je na poduzimanje konkretnih aktivnosti s ciljem donošenja novih, te promjena postojećih javnih politika fokusiranih na rješavanje različitih društveno-političkih problema. "Kroz zagovaračke koalicije stvaraju se mreže i zajednice javnih politika kao važne karike i osnove za izgradnju i provedbu zagovaračkih strategija. Razrađene i jake zagovaračke strategije utječu na donositelje javnih politika. Novi instrument pretpristupne pomoći Bosni i Hercegovini i ostale zemlje kandidati i potencijalni kandidati za članstvo u EU,

${ }^{35}$ E. Kuka, Javne politike, 105. 
IPA II (2014-2020), uveo je značajne novine kada je u pitanju civilno društvo" (Proposal IPA II). Važno je naglasiti kako se tokom određenog vremenskog perioda svog razvoja i djelovanja, NVO Centri civilnih inicijativa (CCI) se fokusirao na jačanje odgovornosti izabranih predstavnika i povećanje transparentnosti, kao i na poboljšanje korisničkog rada predstavnika vlasti. CCI je bio sve više i više orijentiran na najviše nivoe vlasti koji su utjecali na javne politike i zagovarali interese građana. "Da bi uticale na kreiranje pojedinih policy, nevladine organizacije često koriste metode lobiranja". ${ }^{36} \mathrm{U}$ Bosni i Hercegovini vladini (državni) akteri još uvijek u dovoljnoj mjeri ne prepoznaju nevladine organizacije i organizacije civilnog društva kao legitimne i respektabilne aktere $\mathrm{u}$ konzultativnom procesu $\mathrm{u}$ domenu zagovaranja, formuliranja i implementiranja javnih politika. "Usljed takvog pristupa u Bosni i Hercegovini, nameće se potrebe radikalne reforme u tom domenu, a ključni nosioci te reforme, pored državnih aktera, trebaju biti nevladine organizacije $i$ organizacije civilnog društva. U Bosni i Hercegovini je trenutno na nacionalnoj razini registrirano preko 26.000 udruženja/udruga $i$ fondacija (Podaci Ministarstva pravde Bosne i Hercegovine" (Zbirni e-registar udruženja i fondacija u Bosni i Hercegovini). Dio ovih novih asocijacija, nastalih zahvaljujući podršci izvana, čini dio nevladinog civilnog sektora (npr. „Helsinški parlament", „Centri civilnih inicijativa“, „Nezavisni biro za humanitarna pitanja“, „Centar za promociju civilnog društva“, „Transparency International"...)" 37

“Građansko organizovanje za demokratiju (GROZD) je najvidljiviji angažman javnog zagovaranja nevladinih organizacija na kreiranju javnih politika u Bosni i Hercegovini. U oktobru 2005. godine, pet organizacija civilnog društva - Centar za promociju civilnog društva, Centri civilnih inicijativa, Transparency International Bosnia and Heryegovina, Fondacija Mozaik i Agencija za lokalne razvojne inicijative su započele pripreme za mobiliziranje snage civilnog društva da snažno utiču na domaće vlasti da posvete maksimalnu pažnju rješavanju najznačajnijih socijalnih i ekonomskih problema stanovnika Bosne i Hercegovine." 38 Prepoznajući važnost uloge civilnog društva u kreiranju javnih politika i EU u Bosni i Hercegovini je provedeno niz aktivnosti na razvoju konsultacija sa civilnim društvom pri izradi propisa. To je doprinijelo da je Bosna i Hercegovina prva u regionu 2006. godine, usvojila Pravila o konsultacijama u izradi pravnih propisa sa civilnim društvom. Redovno se provode javne konsultacije prije svega pri izradi zakonskih i podzakonskih akata. Jačanjem javnih politika, civilni dijalog ima značajniju ulogu i jedan je od uslova na putu ka punopravnom članstvu Bosne i Hercegovine u Evropsku uniju i to

\footnotetext{
36 Isto.

37 Ismet Sejfija, Povijesne predispozicije $i$ aktuelni razvoj građanskih asocijacija u Bosni $i$ Hercegovini, "Friedrich Ebert Stiftung", Sarajevo 2008, 125.

38 Nives Miošić, ur. et al, Priručnik za analizu javnih politika, EU \& Ured za udruge Republike Hrvatske, Zagreb 2007, 11.
} 
zbog implementacije koncepta demokratije i ljudskih prava te efikasnije $\mathrm{i}$ transparentnije uprave. Problem negativno utiče na povezivanje nevladinih organizacija s okruženjem Evropske unije. Boljom konekcijom nevladine organizacije bio bi riješen problem jer bi one imale veću inozemnu potporu, koja predstavlja temeljni podsticaj razvoju ovih organizacija. Jačanjem javnih politika, civilni dijalog ima značajniju ulogu i jedan je od uslova na putu ka punopravnom članstvu Bosne i Hercegovine u Evropsku uniju i to zbog implementacije koncepta demokratije $\mathrm{i}$ ljudskih prava te efikasnije $\mathrm{i}$ transparentnije uprave. Ukoliko ne dođe do jačanja javnih politika, civilni sektor neće imati značajniju ulogu te ce problem potrajati ukoliko se ne riješi. Prepoznajući važnost uloge civilnog društva u kreiranju javnih politika i EU u Bosni i Hercegovini je provedeno niz aktivnosti na razvoju konsultacija sa civilnim društvom pri izradi propisa. To je doprinijelo da je Bosna i Hercegovina prva u regionu 2006. godine, usvojila Pravila o konsultacijama u izradi pravnih propisa sa civilnim društvom. Važnost rješavanja problema se krije u izradi web aplikacija kao što je „e-Participacija“ koje bi civilnom društvu omogućile aktivno uključivanje u proces izrade propisa, strateških i operativnih dokumenata institucija Bosne i Hercegovine, kao i u proces oblikovanja javnih politika. Ukoliko u skorije vrijeme se ne poduzmu konkretni koraci i aktivnosti problem neće biti riješen te se neće redovno provode javne konsultacije prije svega pri izradi zakonskih i podzakonskih akata.

\section{Metodologija istraživanja i hipotetički okvir}

Niz je prednosti umrežavanja nevladinih organizacija iz Bosne i Hercegovine sa drugim organizacijama iz Evropske unije u cilju lakše implementacije određenog projekta, jačanja kapaciteta ali i lakšeg dobivanja finasijskih sredstava kako od lokalnih tako i stranih donatora. Ključne stvari za apliciranje na fondove od donatora iz Evropske unije jesu specijalizacija i dovoljno jaki operativni i finasijski kapaciteti i upravljanje projektima nevladinih organizacija. Umrežavanje nevladinih organizacija $\mathrm{s}$ drugim organizacijama iz EU može biti presudno za dobivanje grantova te postajanjem respektabilnog aktera u zagovaranju javnih politika u Bosni i Hercegovini. Prilikom objavljivanja javnih poziva za dodjeljivanje sredstava uslov da projektne prijave nevladinih organizacija jeste da one budu u partnerstvu $\mathrm{s}$ barem još jednim NVO-om, a kako bi postale važan kvalifikacijski kriterij. Kriterij često nalaže da je partnerski NVO iz države članice EU, države kandidatkinje ili iz države gdje se projekat implementira. U Bosni i Hercegovini postoje mnoge formalne i neformalne mreže nevladinih organizacija formirane na temelju interesa podsektora (npr. okoliš, mladi ili žene) ili geografskog položaja. Prema HTSPE / Kronauer studiji, 52\% NVO-a u 
Bosni i Hercegovini su članovi neke lokalne NVO mreže, dok njih $27 \%$ učestvuju ili su dio najmanje jedne međunarodne mreže (HTSPE / Kronauer. ${ }^{39}$ "Ipak, nevladin sektor mora uložiti znatno više napora u koordinaciji jer postoji čitav niz slučajeva dupliranja aktivnosti. Imajući u vidu pogodnosti i koristi koje umrežavanje i partnerski odnos između NVO-a može donijeti organizacijama, neophodno je raditi na podizanju svijesti o svim pogodnostima, ali i na vještinama dijaloga, zastupanja, planiranja, te dogovarati zajedničke ciljeve, programe i projekte. Dobro umrežene organizacije imaju jače kapacitete za saradnju sa lokalnim i višim nivoima vlasti, ali još važnije - imaju sposobnosti i kvalifikacije za dobivanje bespovratnih sredstava iz fondova Evropske unije". ${ }^{40}$ "Umreženost organizacija i inicijativa daje posebnu snagu civilnom društvu. Umreženost i povezanost može biti posredovana različitim interesima. Na primjer, sve organizacije civilnog društva mogu naći zajednički interes u izgradnji povoljnijeg zakonskog i osobito poreznog okvira za njihovo djelovanje. Ako veći broj organizacija nastupi zajedno te iskoristi udružene potencijale, veći su izgledi da ostvare zajedničke ciljeve. U razvijenijim zemljama ovakve organizacije imaju bitnu ulogu. One se redovno pojavljuju kao partner vladi u pregovorima, a pružaju i različite oblike tehničke pomoći radi izgradnje kapaciteta svojih članica. Na primjer, u svijetu se redovito navodi primjer organizacije National Council of Voluntary Organisations u Velikoj Britaniji. U Njemačkoj je praksa da svaka nevladina organizacija pripada nekoj od krovnih organizacija po područjima djelovanja. Brojni inostrani stručnjaci koji su pružali tehničku pomoć za razvoj civilnog društva u tranzicijskim zemljama veoma su često bili zaokupljeni idejom osnivanja krovne nacionalne organizacije koja bi predstavljala sektor prema vladi i cjelokupnoj javnosti”, ${ }^{41}$

"U posljednjih desetak godina civilni sektor izrastao je u vrlo respektabilnog partnera vladi, a svojim idejama i uputama bi mogao dati veliki doprinos". ${ }^{42}$ "Civilno društvo izraz je ukupnih okolnosti u kojima nastaje ili traje. Nevladin sektor u Bosni i Hercegovini također predstavlja izraz aktuelnog društveno-političkog konteksta, u strukturalnom i funkcionalnom smislu, i nije tek "implantat" nastao intervencijom međunarodne zajednice, ali, ova intervencija je ostavila Ii još uvijek ostavlja duboke tragove u poratnom razvoju nevladinog sektora u Bosni i Hercegovini." ${ }^{\text {43 }}$

\footnotetext{
${ }^{39}$ Samir Omerefendić, ur, Priručnik za nevladine organizacije u Bosni $i$ Hercegovini, EU \& UNDP \& Ministarstvo pravde Bosne i Hercegovine, Sarajevo 2014, 84. (dalje: S. Omerefendić, Priručnik za nevladine organizacije).

${ }^{40}$ S. Omerefendić, Priručnik za nevladine organizacije, 84.

${ }^{41}$ Gojko Bežovan, Struktura civilnog društva u Hrvatskoj, Politička misao, vol. XXXIX, br. 1, 2002, 63-87.

42 Ranka Ninković-Papić, at al, Izvještaj o procjeni socijalnog poduzetništva u Bosni $i$ Hercegovini, FSU u BiH, august 2012, 30.

${ }^{43}$ Ismet Sejfija, NVO sektor u BiH, tranzicijski izazovi, Bosanska riječ, Tuzla 2009, 9.
} 
- H0: Umrežavanje sa susjednim zemljama članicama EU pozitivno utiče na značaj koji nevladine organizacije imaju u zagovaranju javnih politika.

- H1: Finansijska potpora institucija Evropske unije pozitivno utice na znacaj koji nevladine organizacije imaju u zagovaranju javnih politika.

- H2: Umrežavanje organizacija u Bosni i Hercegovini (od strane motivisanih pojedinaca) jačaju se osnove za provedbu zagovaračkih strategija što pozitivno utiče na zagovaranje javnih politika.

- H3: Kroz uticaj nevladinih organizacija i interesnih skupina (stakeholders) povećava se vjerovatnoća donošenja i realizacije javne politike od strane javnih aktera.

Nezavisne varijable su povezivanje nevladinih organizacija s okruženjem Evropske unije i inostranom potporom kao temeljnom podsticaju razvoju; Zagovaranje konkretnih aktivnosti; Programi za potporu rada nevladinih organizacija; Finansijska potpora institucija Evropske unije; Kreiranjem mreža javnih politika od strane motiviranih pojedinaca te uticaj interesnih skupina (stakeholders); Podrška Evropske unije u provedbi zagovaračkih strategija; U zavisne varijable se ubraja: Uticaj nevladinih organizacija na kreiranje javnih politika; Povećanje respektabilnosti kod državnih aktera; Jačanje pozicije zagovaranja nevladinih organizacija; Jačanje osnove za provedbu zagovaračkih strategija; Donošenje i realizacija javne politike od strane javnih aktera; Indikatori su: Izvještaj o uključenosti aktera civilnog društva u kreiranju javnih politika; Dobijanje respektabilnosti nevladinih organizacija od strane državnih aktera; Broj nevladinih organizacija koje dobijaju operativnu finansijsku podršku EU institucija; Mreže i zajednice javnih politika koje provode zagovaračke strategije; Kreiranje mreže javnih politika provode se zagovaračke strategije te donošenje novih, te promjena postojećih javnih politika.

U nastavku opis načina mjerenja nezavisnih varijabli i veza sa zavisnom varijablom odnosno pretpostavke o mogućem uticaju jedne na drugu te se pozvalo na rad The English Voluntary Sector: how Volunteering and Policy Climate Perceptions Matter autora Kendall J; Mohan J; Brookes N; Yoon, Y. (2018). kao primjer mješovitih metoda, koje se u ovom istraživanju oslanjaju na potencijalne snage kvantitativnih metoda, u cilju istraživanja različite perspektive. Mjerenje varijabli će u najvećem broju biti izvršene metodom ispitivanja dok će pojedine biti mjerene analizom (sadržaja) dokumenata i metodom studije slučaja (Case Study). Kada je u pitanju objašnjenje teorijske pozadine i odnose između konstrukata, veoma važno je navesti Izvještaj o uključenosti aktera civilnog društva u kreiranju javnih politika te dobijanje respektabilnosti nevladinih organizacija od strane državnih aktera. Pored toga, važno je navesti broj nevladinih organizacija koje dobijaju operativnu finansijsku podršku EU institucija te mreže i zajednice javnih politika koje provode zagovaračke strategije. Osim toga, za kraj je važno 
navesti neophodnost kreiranja mreže javnih politika provode se zagovaračke strategije i donošenje novih, te promjena postojećih javnih politika. Za potrebe naučnih istraživanja, bit će primjenjene osnovne i općenaučne metode naučnih istraživanja. Za potrebe empirijskog istraživanja, korištene su metode pribavljanja podataka: analiza (sadržaja) dokumenata, metod ispitivanja (tehnika ankete, instrument anketni upitnik), te metoda studije slučaja (Case Study). Komparativnim metodom, omogućilo se istraživanje utjecaja i mehanizma utjecaja nevladinih organizacija u društvima sa različitim stepenom socio-ekonomskog razvoja. Teorijski model kao i prikupljanje podataka referirano je na upitnik iz političke analize autora autora Randalla Puljek-Shank „Iznad okvira projekata: lokalni legitimitet i zagovaranje civilnog društva u Bosni i Hercegovini“", kao i njegovog istraživačkog članka pod nazivom Dead letters on a page? Civil agency and inclusive governance in neopatrimonialism i ,Iznad okvira projekata: lokalni legitimitet i zagovaranje civilnog društva u Bosni i Hercegovini“" autora Puljek-Shank, R. (2020). ${ }^{44}$ Osim toga konsultovalo se i istraživanje: Nongovernmental Organizations' Policy Advocacy and Government Responsiveness in China autora Zhang, Ch. (2017). ${ }^{45}$ Anketno istraživanje je provedeno na lokalnom, kantonalnom, entitetskom te državnom nivou na reprezentativnom i stratificiranom uzorku (10\% - prema statističkoj metodi), a obuhvatilo je rukovodioce i aktiviste nevladinih organizacija, te službenike organa državne uprave (ministarstva i državne upravne organizacije).

"Prema podacima Zbirnog registra fondacija i udruženja u Bosni i Hercegovini (http://zbirniregistri.gov.ba/Home), ukupan broj je 25.646, a broj stvarno aktivnih je teško utvrditi. Analiza aktivnih i neaktivnih NVO na uzorku od 1.000 nasumično odabranih NVO, ukazuje da 56,4\% registriranih nije aktivno, tj. da nije moguće uspostaviti bilo koji oblik kontakta s njima na osnovu dostavljenih podataka u registre udruženja i fondacija", 46 "Okviran broj aktivnih NVO u Bosni i Hercegovini je 11.182. Kada je riječ o područjima rada, civilnim društvom u Bosni i Hercegovini dominiraju organizacije civilnog društva aktivne u polju sporta i rekreacije $(28,81 \%)$, u promociji socijalno-ekonomskih prava određenih društvenih grupa $(21,55 \%)$ i zalaže se za interesi profesionalnih udruženja (9,21\%). Najmanje je NVO aktivan u oblastima religije ili duhovnosti $(0,29 \%)$, međunarodna saradnja $(0,53 \%)$ i na polju zaštite i spašavanja $(0,80 \%)$ ". ${ }^{47}$ Nakon ovog istraživanja, dobijeni

\footnotetext{
${ }^{44}$ Randall Puljek-Shank, Dead letters on a page? Civic agency and inclusive governance in neopatrimonialism, Radboud Repository of the Radboud University Nijmegen, 2020; R. Puljek-Shank, Iznad okvira projekata: lokalni legitimitet i zagovaranje civilnog društva u Bosni i Hercegovini, Friedrich-Ebert-Stiftung, FES, Sarajevo 2020.

45 Changdong Zhang, Nongovernmental Organizations' Policy Advocacy and Government Responsiveness in China, Journals Sagepub, vol. 47, Issue 4, 2018, 3.

${ }^{46}$ Goran Žeravčić, ur, Studija mapiranja OCD u Bosni i Hercegovini, European Union \& EPRD, Sarajevo 2016, 52. (dalje: G. Žeravčić, Studija mapiranja).

${ }^{47}$ G. Žeravčić, Studija mapiranja, 60.
} 
rezultati su indikovani određenim pokazateljma u odnosu na postavljene parametre kada je u pitanju njihova analiza. Dobijeni rezultati su se analizirali kvalitativno i kvantitativno, a nakon predstavljeni grafički i tabelarno (koristeći programm SPSS). Rezultati su obrazloženi na osnovu stavova do kojih se došlo od strane ispitanika, kao i pribavljenih podataka. Dobijeni rezultati analizirani su kroz prizmu izloženih polaznih teorijskih stavova, zakonske regulative, kao i iskustava iz prakse. U svrhu dolaska do jasnih zapažanja koja bi se mogla porediti između različitih grupa ispitanika, u analizi je data prednost tumačenju ukupnih rezultata nad tumačenjem pojedinačnih tvrdnji. Od izuzetne je važnosti i primjena integrativnog koncepta saradničke odgovornosti među nevladinim organizacijama prilikom zagovaranja javnih politika te preporuka niz proaktivnih i praktičnih promjena strategija.

\section{Istraživačke pretpostavke}

Oblast slobode udruživanja u Bosni i Hercegovini je u skladu sa međunarodnim standardima, prije svega Europskom konvencijom za zaštitu ljudskih prava i osnovnih sloboda. Odsustvo poštivanja univerzalnih ljudskih prava segmenata nevladinih organizacija, u praksi nevladinog sektora u Bosni i Hercegovini je dovelo do međusobnog suprostavljanja uticaja na zagovaranje i kreiranje javnih politika. Kao primjer se navodi aktivnost pojedinih nevladinih organizacija na usvajanju zakona koji u neravnopravan položaj stavljaju ne ratne invalide te daju bolji status. Bosanskohercegovačkom društvu i državi je neophodno donošenje javnih politika. Pod uticajem nevladinih organizacija, veliki broj općinskih vijeća ili načelnika su donijeli određene pravne norme (odluke, zaključke, naredbe). Ipak, javnost nije upoznata o javnim raspravama (debatama) o određenoj odluci ili budžetu $u$ organizaciji nevladinih organizacija. Od velikog je značaja da civilno društvo i nevladin sektor kao njegov dio, zastupa civilnost u svim oblicima državnog i društvenog uređenja. Nevladin sektor je inicirao, vodio i uspješno realizovao veliki broj aktivnosti kroz neinstitucionalne mehanizme, sa ciljem kreiranja javnih politika, posebno kroz kampanje javnog zagovaranja i monitoring rada izvršne i zakonodavne vlasti, edukacije i kontrole tajnih aktivnosti. Od velike je važnosti istražiti u kojoj je mjeri primjena institucionalnih mehanizama saradnje vladinog i nevladinog sektora u Bosni i Hercegovini u skladu sa mehanizmima i praksom Europske unije. Osim toga, važno je istražiti mogućnost učestvovanja u "ranoj fazi" (podnošenja nacrta odluka) podnošenja inicijativa i donošenja odluka. Osim toga, važno je i pronaći uzroke niskog nivoa umreženosti nevladinih organizacija, kao i nedostataka za predlaganje alternativnih politika. Institucionalne metode uticaja nevladinih organizacija su: javno zagovaranje, monitoring, politička participacija, kontrola tajnog u politici i edukacija. Ipak, najznačajnije su institucionalne metode utjecaja nevladinih organizacija na 
kreiranje javnih politika prisutnih u praksi bosanskohercegovačkog nevladinog sektora. Putem javnog zagovaranja, Građansko organizovanje za demokratiju (GROZD) je bio najindikativniji angažman javnog zagovaranja nevladinih organizacija na kreiranje javnih politika u Bosni i Hercegovini. Njegov cilj je bio usvajanje "Građanske političke agende - Građanske platforme". Osim javnog zagovaranja, jedna od najznačajnijih institucionalnih metoda je monitoring, odnosno posmatranje situacije, praćenje i izvještavanje o uočenom. Ovo je jedna od najzastupljenijih funkcija u praksi nevladinih organizacija u Bosni i Hercegovini, koje imaju za cilj povećanje institucionalne i individualne odgovornosti, efikasnosti, efektivnosti i transparentnosti putem periodičnog prezentiranja rezultata njihovog rada javnosti. Pod političkom participacijom spada process dobrovoljnog (volonterskog) učešća pojedinaca i socijalnih grupa u iniciranju, razmatranju, donošenju političkih odluka organizacija i institucija. Rezultati koje se očekuju unutar istraživanja daju naučni, empirijski i aplikativni doprinos.

U naučnom smislu, očekivani doprinos se sastoji u sublimiranju najnovijih teorijsko-empirijska saznanja iz oblasti javnih politika; Doprinosu boljem razumijevanju mnoštva novih pojmova, koncepata i postupaka odnosa civilnog društva, nevladinog sektora i javne politike koji su afirmisani u praksi razvijenih zemalja; Doprinosu boljem razumijevanju uloge nevladinog sektora (udruženja) u javnom zagovaranju; Analizi i kompariranju aktuelnih teorija pravno političkog okvira, strukture, veličine, faktora razvoja nevladinog sektora; Ocjene trenutnog stanja mehanizma uticaja na kreiranje agendi javnih politika; Prikaza teorijskog okvira nevladinog sektora u Bosni i Hercegovini; Formulisanja mjere za unutrašnje strukture i umreženosti nevladinih organizacija te definisati njihov broj, strukturu i tipove.

U empirijskom smislu očekivani naučni doprinos se sastoji u utvrđivanju u kojoj mjeri je uloga i uticaj nevladinih organizacija na kreiranje javnih politika u bosanskohercegovačkom društvu; Identificiranju institucionalne i neinstitucionalne metode donošenja javnih politika te njihov monitoring; Utvrđivanju nivoa usklađenosti nevladinog sektora i javnih politika Bosne i Hercegovine sa modelom EU; Utvrđivanju mogućih ograničenja i probleme kod zagovaranja javnih politika od strane nevladinih organizacija u Bosni i Hercegovini; Ukazivanju na značaj slobode udruživanja u Bosni i Hercegovini i njenu usklađenost sa međunarodnim standardima prije svega Evropskom konvencijom za zaštitu ljudskih prava i osnovnih sloboda. U aplikativnom smislu, rezultati ovoga istraživanja mogu imati široku primjenu: Za građane u Bosni i Hercegovini, kako bi bolje razumjeli javne politike i načine na koje mogu ostvariti svoja prava; Za promociju poštivanja univerzalnih ljudskih prava od strane nevladinih organizacija u Bosni i Hercegovini; Za bosanskohercegovačko civilno društvo i nevladin sektor kao njegov dio, prilikom zastupanja civilnosti u svim oblicima državnog i društvenog uređenja; Za predlaganje alternativnih politika i razvoj civilnog društva zasnovanog na demokratiji i poštivanju univerzalnih standarda o 
ljudskim pravima; Za nevladin sektor, kako bi stekli bolje razumijevanje njihove uloge $\mathrm{u}$ donošenju javnih politika u Bosni i Hercegovini. Plan aktivnosti u logičnom redoslijedu u prvoj fazi najprije bi se ticao prikupljanja primarnih podataka o značaju nevladinih organizacija kdo donošenja javnih politika u Bosni i Hercegovini. Pregled literature bi bio kroz pristup podacima $\mathrm{u}$ okviru Arhive podataka iz društvenih nauka u Bosni i Hercegovini DASS-BiH, pristup stručnoj literature (COBISS i EBSCO), pristup bazama istraživačkih pitanja relevantnih za donošenje politika u Bosni i Hercegovini (Question Bank), te pristup softverima i drugim alatima za istraživanje (poput mikrosimulacijskih modela).

Anketno istraživanje je provedeno na reprezentativnom uzorku rukovodilaca nevladinih organizacija, a uzorak bi bio: $10 \%$ nevladinih organizacija na lokalnom, $10 \%$ na kantonalnom, $10 \%$ na entitetskom, te $10 \%$ na državnom nivou. Anketa bi bila sprovedena i na uzorku od 194 formalnih donosioca javnih politika (po jedan predstavnik 9 državnih ministarstava, 16 ministarstava u Federaciji Bosne i Hercegovine, 16 ministarstava u Republici Srpskoj, jednog predstavnika iz Vlade Brčko Distrikta, po jedan predstavnik iz vlada deset kantona u Federaciji Bosne i Hercegovine i po jedan predstavnik 142 općine u Bosni i Hercegovini. Za potrebe ovog istraživanja ukupno je 201 ispitanika odgovorilo na anketni upitnik.

\section{Pretpostavke istraživanja}

Vrijednost Cronbach-ovog Alfa koeficijenta za svaku je stavku bila je između 0,81 i 0,91 , što ukazuje na visoku pouzdanost pitanja iz korištenog upitnika. Cronbach-ov Alfa koeficijent za sve konstrukte je viši od 0,81 ili više, što smatra izuzetno prihvatljivimodnosno izvrsnim rezultatom. Nakon prikupljanja podataka, oni su uneseni u SPSS bazu podataka i kao prvi korak testirani su na internu konzistentnost svakog odjeljaka / konstrukata. Prikaz Cronbach-ovog Alfa koeficijenta po stavkama nalaze se u prikazanoj donjoj tabeli.

Tabela 1. Cronbach Alpha coefficients za svaki konstrukt/odjeljak.

\begin{tabular}{|c|c|}
\hline Konstrukti / odjeljci: & Cronbach's Alpha \\
\hline FAJP - Formalni akteri i javne politike & .812 \\
\hline NAJP - Neformalni akteri i javne politike & .851 \\
\hline IPN - Inozemna potpora NVO & .813 \\
\hline U - Umrežavanje & .911 \\
\hline
\end{tabular}

Detaljnom analizom može se saznati kako je veoma mali broj pitanja koja nisu prema Cronbach's Alpha vrijednostima, odnosno nisu povezana $\mathrm{s}$ 
ključnim konstruktima ciljanim $u$ istraživačkom modelu. $U$ skladu sa predpostavkama Centralne granične teoreme, primijenjene su neparametarske tehnike i test, s obzirom na blagi iskorak raspodjele udesno za svaku varijablu konstruiranog modela. Analiza normalnosti raspodjele najvažnijih varijabli odnosno konstrukata je prikazana tabelarno i grafički gdje se može vidjeti kako svaka varijabla nema potpuno normalnu raspodjelu.

Metode korelacije i regresije korištene su u ovoj studiji za ispitivanje veza i međusobnih utjecaja između različitih konstrukcija dokazivanjem odabranih pretpostavki koje se tiču utjecaja pojedinih neovisnih varijabli na zavisnu varijablu modela, odnosno pojedinih prediktorskih varijabli na kriterijsku varijablu, jer je to nije klasičan eksperiment.

\section{Ocjenjivanje stavova o značaju nevladinih organizacija u donošenju javnih politika u Bosni i Hercegovini}

Istraživanje koje je provedeno ima za cilj identificiranje veza koje postoje između varijabli koje mjere način funkcionisanja i umreženost bosanskohercegovačkih nevladinih organizacija sa mjerilom njihovog uticaja na donošenje javnih politika. U nastavku se nalazi grafički prikaz rezultata anketnog istraživanja ispitanik koji su zaokružili jedan od ponuđenih brojeva na skali od 1 do 5 za svaku od navedenih tvrdnji. Time su izraziti ocjenu svog slaganja ili ne slaganja sa navedenim tvrdnjama, a značenje brojeva je sljedeće: (1) Potpuno se ne slažem, (2) Pretežno se ne slažem, (3) Nemam mišljenje, (4) Pretežno se slažem, (5) Potpuno se slažem.

- H0: Uspješnim umrežavanjem sa susjednim zemljama članicama Evropske unije nevladine organizacije postaju respektabilan akter $\mathrm{u}$ donošenju javnih politika u Bosni i Hercegovini.

- H1: Umrežavanje sa susjednim zemljama članicama EU pozitivno utiče na značaj koji nevladine organizacije imaju u zagovaranju javnih politika.

- H2: Finansijska potpora institucija Evropske unije pozitivno utice na značaj koji nevladine organizacije imaju u zagovaranju javnih politika.

- H3: Umrežavanje organizacija u Bosni i Hercegovini (od strane motivisanih pojedinaca) jačaju se osnove za provedbu zagovaračkih strategija što pozitivno utiče na zagovaranje javnih politika.

Pošto podaci nema normalnu raspodjelu podataka prilikom testiranja, što potvrđuje negativna asimetrija Skewness iznosi - .140 a Sig je .000 prema Kolmogorov-Smirnov testu za uzorke veće od 100 koristit će se neparametrijske tehnike (Hi2, Spearmanov koeficijent, Mann-Whitney U Test, regresija i drugo). Testiranje statandardne nezavisnosti dviju kategoričkih varijabli hi-kvadrat testom u programu SPSS upoređene su H0 i H1: 
Umrežavanje sa susjednim zemljama članicama Evropske unije pozitivno utiče na značaj koji nevladine organizacije imaju u zagovaranju javnih politika.

\title{
Grafikon 1.
}

\begin{abstract}
Umrežavanjem sa susjednim zemljama članicama Evropske unije nevladine organizacije postaju respektabilan akter u zagovaranju javnih politika u Bosni i Hercegovini.

201 odgovor
\end{abstract}

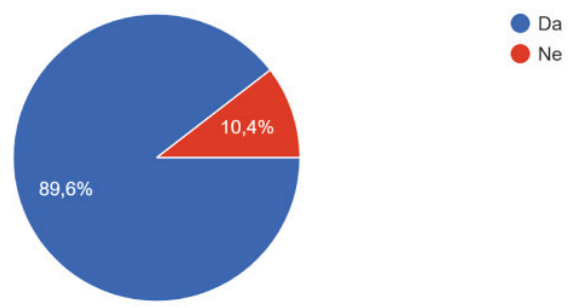

$\mathrm{Na}$ pitanje kako umrežavanje sa susjednim zemljama članicama Evropske unije nevladine organizacije postaju respektabilan akter $u$ zagovaranju javnih politika u Bosni i Hercegovini pozitivno je odgovorilo $89,6 \%$ ispitanika dok je samo $10,4 \%$ odgovorilo negativno.

\section{Grafikon 2.}

\begin{abstract}
Značajan je uticaj nevladinih organizacija na zagovaranje i kreiranje javnih politika. 201 odgovor
\end{abstract}

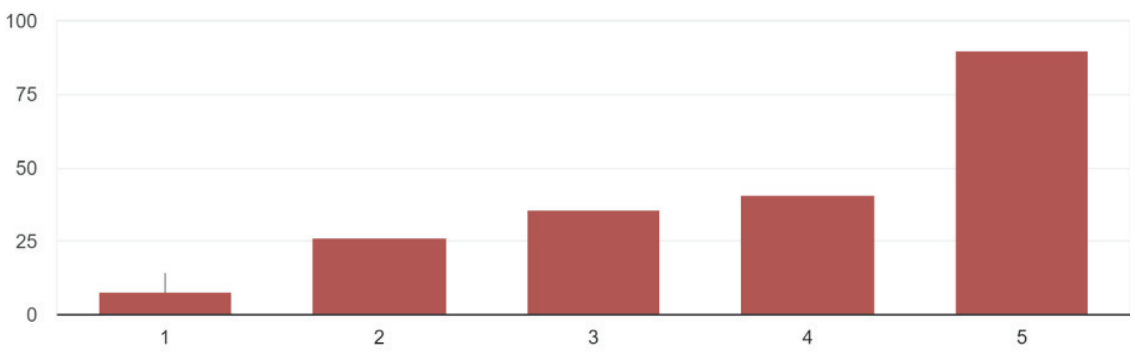

Daleko najveći broj ispitanika $(44,8 \%)$ je kazao kako se u potpunosti slaže sa tvardnjom kako je značajan uticaj nevladinih organizacija na zagovaranje i kreiranje javnih politika. 


\section{Grafikon 3.}

Finansijska potpora institucija Evropske unije doprinosi jačanju poziciju nevladinih organizacija kod donošenja i implementiranju javnih politika.

201 odgovor

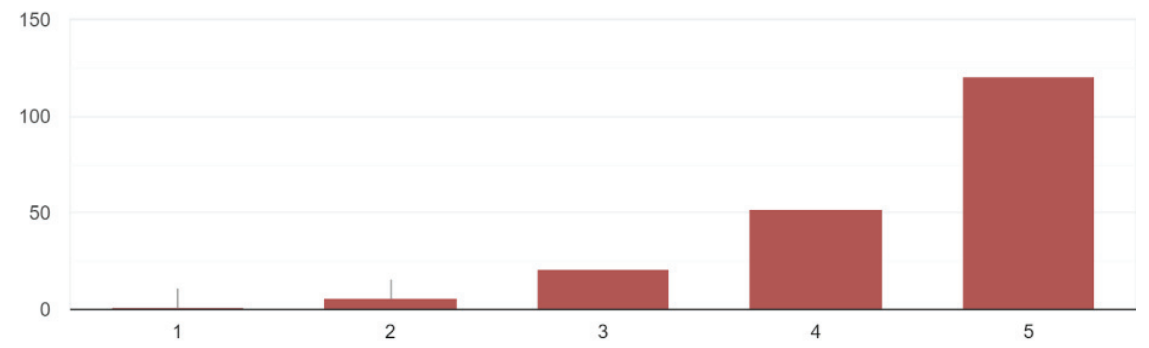

Kako finansijska potpora institucija Evrospke unije doprinosi jačanju pozicije nevladinih organizacija kod donošenja i implementacije javnih politika u potpunosti se slaže $60,2 \%$ ispitanika.

\section{Grafikon 4.}

Veliki uticaj na donošenje i realizaciju javne politike od strane javnih aktera vrše interesne skupine (stakeholders).

201 odgovor

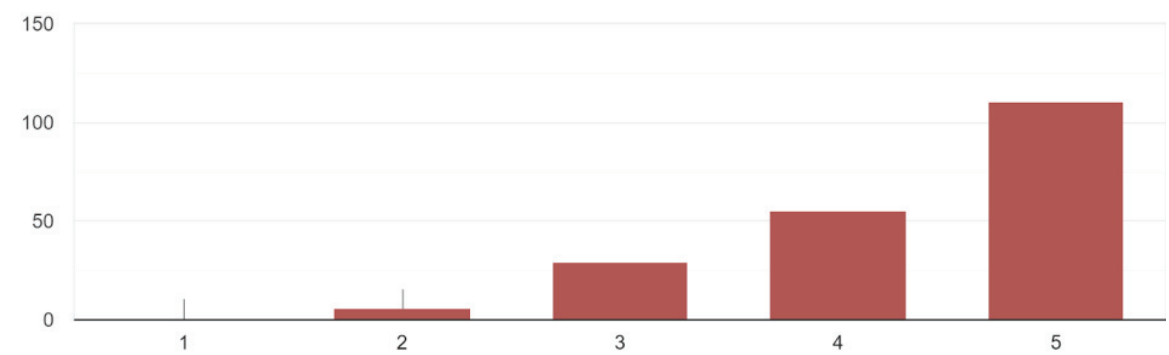

Veliki uticaj na donošenje i realizaciju javne politike od strane javnih aktera vrše interesne skupine (stakeholders) u potpunosti se slaže 55,2\% ispitanika. 


\section{Grafikon 5.}

Državni akteri odnosno nadležni vladini organi vlasti iniciraju konkretne aktivnosti donošenja javnih politika u saradnji sa neformalnim donosiocima.

201 odgovor

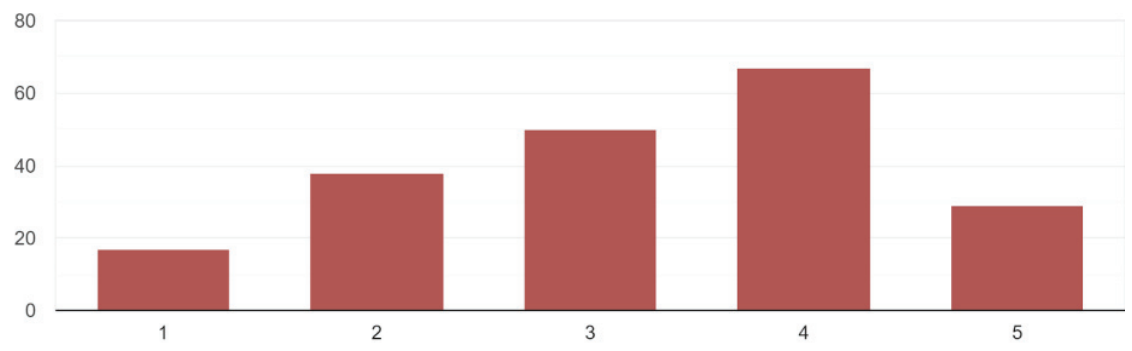

S druge strane, čak 24,9\% ispitanika nemam mišljenje, dok njih 33,3\% se pretežno slaže kako državni akteri odnosno nadležni organi vlasti iniciraju konkretne aktivnosti donošenja javnih politika u saradnji sa neformalnim donosiocima.

\section{Grafikon 6.}

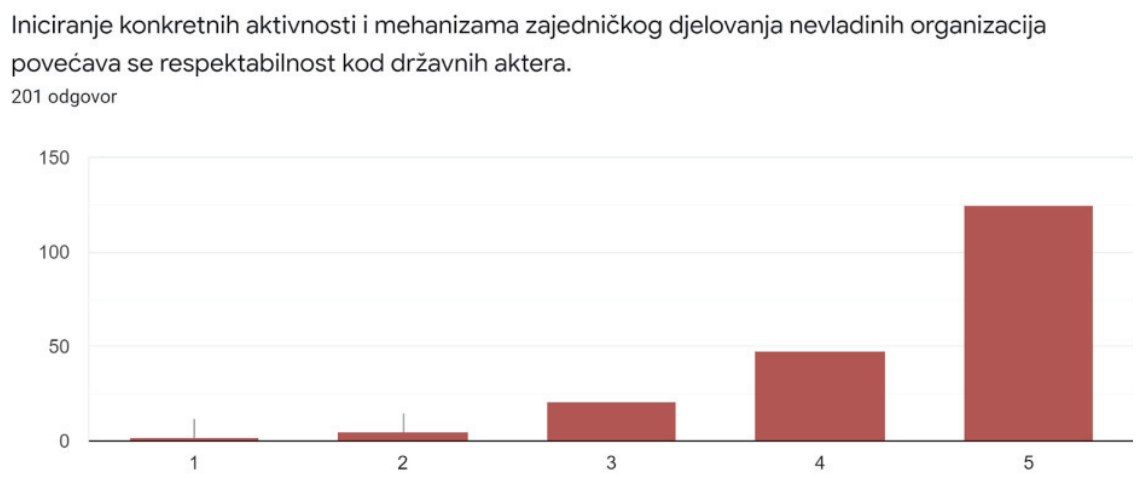

I za kraj, u potpunosti se slaže $44,8 \%$ ispitanika kako iniciranjem konkretnih aktivnosti i mehanizama zajedničkog djelovanja nevladinih organizacija se povećava respektabilnost kod državnih aktera. U ishodu hi-kvadrat testa vidljiva je nezavisnost ovih dviju kategoričkih varijabli. Tako se u Pearson Chi-Square vidi vrijednost statistika koja je $219.906^{\text {a }}$, df je 10 dok je Asymp. Sig. (2-sided) odnosno približna dvostrana vjerovatnoća je .000 iz čega se vidi kako su ove dvije varijable u asocijaciji. 
Tabela 2. Testiranje hipoteza Ho i H1. Chi-Square Tests

\begin{tabular}{|c|c|c|c|}
\hline & Value & df & $\begin{array}{c}\text { Asymp. Sig. } \\
\text { (2-sided) }\end{array}$ \\
\hline Pearson Chi-Square & $219.906^{\mathrm{a}}$ & 10 & .000 \\
Likelihood Ratio & 30.832 & 10 & .001 \\
N of Valid Cases & 201 & & \\
\hline
\end{tabular}

a. 12 cells $(66.7 \%)$ have expected count less than 5 . The minimum expected count is .00 .

Testiranje statandardne nezavisnosti dviju kategoričkih varijabli hi-kvadrat testom u programu SPSS upoređene su "nul-hipoteza" i H1. U ishodu hi-kvadrat testa vidljiva je nezavisnost ovih dviju kategoričkih varijabli. Tako se u Pearson Chi-Square vidi vrijednost statistika koja je $219.906^{\text {a }}$, df je 10 dok je Asymp. Sig. (2-sided) odnosno približna dvostrana vjerovatnoća je .000 iz čega se vidi kako su ove dvije varijable u asocijaciji.

Tabela 3. Testiranje hipoteza Ho i H1.

Symmetric Measures

\begin{tabular}{|c|c|c|}
\hline & Value & Approx. Sig. \\
\hline \multirow{4}{*}{ Contingency Coefficient } & 1.046 & .000 \\
\hline & .740 & .000 \\
\hline & .723 & .000 \\
\hline & 201 & \\
\hline
\end{tabular}

a. Not assuming the null hypothesis.

b. Using the asymptotic standard error assuming the null hypothesis.

U gore navedenim resuzltatima Cramer's $\mathrm{V}$ vidimo kako su oni $>0,6$ što znači da su rezultati jaki a polja veoma povezana. Upotrebom Hi-kvadrat testa nezavisnosti, potvrđena je teza o statističkoj podudarnosti fi $=1.046$.

Tabela 4. Testiranje hipoteza Ho i H2.

Chi-Square Tests

\begin{tabular}{|c|c|c|c|}
\hline & Value & df & $\begin{array}{c}\text { Asymp. Sig. } \\
\text { (2-sided) }\end{array}$ \\
\hline Pearson Chi-Square & $78.960^{\mathrm{a}}$ & 16 & .000 \\
Likelihood Ratio & 77.739 & 16 & .000 \\
N of Valid Cases & 201 & & \\
\hline
\end{tabular}

a. 16 cells $(64.0 \%)$ have expected count less than 5 . The minimum expected count is .04. 
Testiranje statandardne nezavisnosti dviju kategoričkih varijabli hi-kvadrat testom u programu SPSS upoređene su: H0 i H2. U ishodu hi-kvadrat testa vidljiva je nezavisnost ovih dviju kategoričkih varijabli. Tako se u Pearson Chi-Square vidi vrijednost statistika koja je 78.960 a, df je 16 dok je Asymp. Sig. (2-sided) odnosno približna dvostrana vjerovatnoća je .000 iz čega se vidi kako su ove dvije varijable u asocijaciji.

Tabela 5. Testiranje hipoteza Ho i H2.

Symmetric Measures

\begin{tabular}{|cc|c|c|}
\hline & & Value & Approx. Sig. \\
\hline \multirow{4}{*}{ Nominal by Nominal } & Phi & .628 & .000 \\
& Cramer's V & .314 & .000 \\
Nof Valid Cases & .532 & .000 \\
N of Vency Coefficient & 201 & \\
\hline
\end{tabular}

a. Not assuming the null hypothesis.

b. Using the asymptotic standard error assuming the null hypothesis.

$\mathrm{U}$ gore navedenim resuzltatima Cramer's V vidimo kako su oni $0.2<$ ES $\leq 0.6$ što znači da su rezultati umjereni a polja umjereno povezana. Upotrebom Hi-kvadrat testa nezavisnosti, potvrđena je teza o statističkoj podudarnosti fi $=0.628$.

Tabela 6. Testiranje hipoteza Ho i H3.

Chi-Square Tests

\begin{tabular}{|c|c|c|c|}
\hline & Value & df & $\begin{array}{c}\text { Asymp. Sig. } \\
\text { (2-sided) }\end{array}$ \\
\hline Pearson Chi-Square & $95.420^{\mathrm{a}}$ & 12 & .000 \\
Likelihood Ratio & 90.851 & 12 & .000 \\
N of Valid Cases & 201 & & \\
\hline
\end{tabular}

a. 11 cells $(55.0 \%)$ have expected count less than 5 . The minimum expected count is .12.

Za kraj su upoređene H0 i H3. U ishodu hi-kvadrat testa vidljiva je nezavisnost ovih dviju kategoričkih varijabli. Tako se u Pearson Chi-Square vidi vrijednost statistika koja je 95.420a , df je 12 dok je Asymp. Sig. (2-sided) odnosno približna dvostrana vjerovatnoća je .000 iz čega vidimo kako su ove dvije varijable u asocijaciji. 
Tabela 7. Testiranje hipoteza Ho i H3.

Symmetric Measures

\begin{tabular}{|c|c|c|c|}
\hline & & Value & Approx. Sig. \\
\hline \multirow{4}{*}{ Nominal by Nominal } & Phi & .691 & .000 \\
& Cramer's V & .399 & .000 \\
Nof Valid Cases & .568 & .000 \\
Nontingency Coefficient & 201 & \\
\hline
\end{tabular}

a. Not assuming the null hypothesis.

b. Using the asymptotic standard error assuming the null hypothesis.

U gore navedenim resuzltatima Cramer's V vidimo kako su oni $0.2<$ ES $\leq 0.6$ što znači da su rezultati umjereni a polja umjereno povezana. Upotrebom Hi-kvadrat testa nezavisnosti, potvrđena je teza o statističkoj podudarnosti fi $=0.691$.

\section{Zaključak}

Prilikom adresiranja određenih društvenih problema mnogo može postići umrežavanjem organizacija civilnog društva, ali da pritom iznikle ideje moraju biti što raznovrsnije, kako bi se došlo do efikasnijih rješenja. Civilni sektor je taj koji, čineći uz javni i poslovni sektor temelj društva, može znatno doprinijeti edukaciji šire javnosti po pitanju različitih društvenih problema. Nakon završetka rata i Dejtonskog sporazuma 1995. godine te uspostave civilnog sektora u Bosni i Hercegovini prošlo je 26 godina i postignuća približno 12.000 nevladinih organizacija je upitna odnosno svrsihodnost osnivanja takvih organizacija. Štetu imidžu nevladinog sektora nanijeli su ljudi koji su iz njega prelazili u političke partije, stvarajući time ogromno nepovjerenje javnosti prema svim civilnim udrugama. Nevladin sektor treba prestati da se bavi sam sobom, izaći iz hibernacije i postati konekcija između građana i sistema, odnosno problema koje građani imaju sa sistemom. Ključna je promjena metodologije rada nevladinog sektora, dekonstrukcija ratne, konfliktne retorike i stavljanje u službu građana. Neophodan je izlazak iz zone komfora i ,življenje“ društvenog aktivizma. Želi li preživjeti, nevladin sektor mora izaći na teren i rješavati konkretne probleme, vidljivije i samostalnije. Pojedine nevladine organozacije su kroz javne intervencije, tekstove i aktivnosti artikulisale alternativu dominantnoj politici etnoidentiteta. Tada je primijećena fragmentiranost i netrpeljivost među akterima nevladinog sektora koji su kontaminirali javni prostor. Cilj je nastaviti aktivnosti u programima društvene pismenosti, $u$ fokusu je trenutno ekološka pismenost koja produktivno organizira radne snage zajednice u cilju zajedničkih interesa. Važno je ujedinjenje fragmentiranog fronta onih koji su već aktivni i onih koji se tek uključuju u procese. Ključni su i transgeneracijski mostovi, načini prenosa znanja i iskustva srednje genracije na mlade, s ciljem sprečavanja 
demografske katastrofe. Pored medija i vjerskih zajednica, građani najviše vjeruju predstavnicima civilnih udruga. Nevladin sektor je jedini prostor slobode i aktivizma u Bosni i Hercegovini, uz to nepodržan od strane vlasti. Kao pozitivne primjere djelovanja istakla je Koaliciju za borbu protiv govora mržnje koja je inicirala izmjene Zakona o govoru mržnje, kao i Mrežu za izgradnju mira, Žensku mrežu, Eko mrežu Bosne i Hercegovine itd. Do problema u saradnji između raznih predstavnika nevladinih organizacija dolazi zbog nedostatka sličnosti u programima i vrijednosnim osnovama, a savezi i gradnja zajedničkog identiteta formiraju se na osnovu sličnosti programa. Ključ uspješnog rada udruga civilnog sektora su osviještenost o državnim i međunarodnim prioritetima kakva je npr. aktuelna borba protiv lažnih vijesti, analiza vlastitih kapaciteta i pošten, sveobuhvatan i transparentan pristup civilnom društvu. Saradnja među nevladinim organizacijama u prošlosti je bila zasnovana na raznim projektima od kojih niko nije imao koristi osim kreatora tih projekata.

Iskusnije nevladine organizacije moraju aktivno raditi na izgradnji sistema koji će obezbijediti zakonsku strukturu kroz koju će građani rješavati svoje probleme. European Endowment for Democracy (EED) podržava nove, neobične, lokalne inicijative poput zaštite rijeka i borbe protiv izgradnje malih hidrocentrala ali protežira i klasične nevladine organizacije. Jedan od primjeri zajedničkog djelovanja nevladinih organizacija iz Evrope i regije poput „Never Work Alone“, inicijative koja je ujedinila evropske sindikaliste i nevladine udruge protiv prisilnog rada i trgovine ljudima kao i „Ne damo naše auto-ceste“ iz Hrvatske gdje su sedam sindikata i nevladine udruge prikupile pola miliona potpisa, uložili preko 600.000 kuna i sproveli referendum kojim je spriječena privatizacija auto-cesta. Nevladine organizacije iz Bosne i Hercegovine ostvaruju saradnju sa organizacijama iz zemalja regiona u cilju poboljšanja zaštite i sigurnosti radnika jer nemaju snage da se sami izbore sa vlastima, zato moraju nastupati zajedno. O ulozi nevladinih organizacija u donošenju javnih politika u Bosni i Hercegovini svjedoči i primjer Centra za građansku suradnju Livno od 1996. godine koji konstantno sarađuje sa medijima i sindikatima. 2003. su pomogli uspostavi prvog sindikata djelatnika u školama. Posljednji prijedlog izmjena zakona u kojemu je Centar za građansku suradnju Livno učestvovao je Zakon o porezima i doprinosima na plate, sa ciljem smanjenja previsoke stope oprezivanja koja bi imala pozitivne efekte na ekonomiju. S druge strane unutar mobilnih timova Unsko-Sanskog kantona uskoro će doći do stvaranju nevladine organizacije koja ce se baviti integracijom migranata $i$ izbjeglica koji žele ostati u Bosni i Hercegovini. Migracioni centar u sklopu projekta neće pružati samo hranu i odjeću nego olakšavati integraciju migranata kroz učenje jezika, pružanje pravne pomoći i izvođenja na tržište rada. Dojam je da društvo ne razumije problematiku migranata. Osobito su na udaru žene koje pomažu migrantima, od strane agresivnih neistomišljenika. Cilj organizacije je saradnja i povezanost migranata sa lokalnim institucijama i međunarodnim faktorima. Organizacija će za početak zaposliti tri migranta i bit 
će spona između vladinih institucija i migranata koji mogu biti i potencijal za domaće tržište rada. Postoji problem umrežavanja i administriranja u kreiranju praktičnih politika ali i da je moguće kreiranje praktičnih politika van projekata.

Od izuzetne je važnosti institucionalizacija građanske participacije tj. nacionalni budžeti bi trebali predvidjeti dio novca za nevladin sektor kako cijeli teret finansiranja ne bi bio na stranim donatorima. Neophodno je povećanje svjesnost o tome da nevladin sektor nije strano tijelo nego dio zajedničkog sistema koji služi kao indikator kvaliteta uprave. Dijalog unutar nevladine mreže ali i sa drugim dijelovima civilnog društva ne može se rješavati na apstraktan način kakav je bila platforma koja je napravljena za koordinaciju na teritoriji Bosne i Hercegovine ali se vremenom na nju zaboravilo. Ranije nije bilo povjerenja građana prema nevladinim organizacijama ali to se sada mijenja. Među različitim akterima nije bilo saradnje, nekoliko organizacija sa sjedištem u Sarajevu ili većim gradovima dobijali su glavninu projekata, neke druge nisu imale razvijene kapacitete za sprovođenje projekata, neke su samo formalno postojale, tako da se izgubilo dosta energije da bi se sve završavalo sa prestankom dotoka finansija od strane donatora. Sada imamo brojne projekte koji jačaju kapacitete lokalne samouprave. U manjim sredinama ne reaguje se na slučajeve kršenja procedura finansiranja nevladinih organizacija koje mogu dobiti novac samo na lokalnom nivou jer se činovnici u opštini lako dogovore sa prekršiteljima. Finansiraju se samo one organizacije koje promoviraju politike vladajućih struktura. Porazno je da većina organizacija neće da se bori u takvim bitkama jer su u pitanju mala sredstva, međutim to su sredstva građana. Mora se uspostaviti sistem evaluacije rada i potencirati transparentnost da bi stvari bolje funkcionisale u budućnosti. I pored činjenice kako na nivou pojedinih kantona imaju različiti prioriteti djelovanja nevladinih organizacija ipak je umrežavanje potrebnije na državnom nivou.

Postavlja se pitanje u kojoj mjeri je iskorišteno savjetodavno tijela pri Vijeću ministara kojem je primarna uloga saradnja sa NVO sektorom. Treba intenzivirati saradnju s tim tijelom da bi se otvorila pitanja poreza, doprinosa, kao i harmonizacije rada nevladinih organizacija. Mnogo projekata i aktivnosti se dupliralo, ne postoji filtriranje od strane države koje bi spriječilo višekratno ponavljanje istih akcija i projekata. Na nedavno održan sastanak između delegacije nevladinog sektora pri Vijeću ministara Bosne i Hercegovine i predstavnika vlasti. Iznijeta je ideja da se ova grupa angažira u lobiranju kod Vijeća ministara da bi se napravio fond za sufinansiranje organizacija koje su dobile projekte u kojima donatori traže vlastito učešće od najmanje 10\% predviđenog budžeta. Predloženo je da se pošalje pismo grupi međunarodnih organizacija u kome bi se tražilo formiranje koordinacionog tijela koje je postojalo prije 10 godina, a u kome bi se predstavnici donatora viđali $\mathrm{i}$ razmjenjivali informacije o apliciranjima i donacijama što bi ujedno spriječilo „dupliranje“ projekata ili odobravanje nekih, ,pomodnih“ projekata, a ne strateški važnih za razvoj medijskog i civilnog sektora. Odbor za civilno društvo, Sektor za civilno društvo pri Ministarstvu pravde Bosne i Hercegovine, 
NVO Vijeće i Centar za promociju civilnog društva (CPCD) ranijih godina su učestvovali u razgovorima sa predstavnicima vlasti gdje je težište bilo na jačanju demokratske kulture dijaloga i saradnje institucija vlasti i civilnog društva u Bosni i Hercegovini. Na tom razgovoru je kao primjer dobre prakse navedena primjena Sporazuma o suradnji između Vijeća ministara Bosne i Hercegovine i nevladinog sektora. U cilju jačeg angažmana nevladinog sektora kod donošenja javnih politika na lokalnom nivou sa akcentom na komunalne, kulturne, obrazovne i turističke, a koje su u interesu javnog i privatnog neophodan je veći angažman i centara za javne politike.

U cilju bolje formulacije javnih politika na lokalnom nivou, neophodan je veći angažman centara za javne politike u Bosni i Hercegovini koji bi se bavili istraživanjem, izradom i edukacijom u domenu javnih politika. Neophodno je kreirati program fokusirana na javne politike za lokalnu zajednicu. Izraditi javnih politika prilagođenih specifičnim problemima određenih lokalnih zajednica. Za njegovu uspostavu moguće je ugovoriti partnersku saradnju sa zainteresiranim lokalnim zajednicama, te na konsultantskom osnovu sarađivati sa datim lokalnim zajednicama, za njih raditi posebno krojene javne politike i pomagati u njihvoj implementaciji. Centri bi radili na usavršavanju i unaprjeđenju upotrebe javnih politika kao okvira za djelovanje pri rješavanju problema i izazova $\mathrm{s}$ kojim se država i društvo svakodnevno suočavaju. Centri bi izrađivali i pomagali u implementaciji prijedloga javnih politika koji su jasni i konkretni, ambiciozni ali provodivi, usklađeni sa strategijama razvoja države, utemeljeni na naučnim istraživanjima i usmjereni primarno ka čovjeku i njegovoj dobrobiti. Program razvoja modela, okvira i alata za javne politike podrazumijeva razvoj i brendiranje jedinstvenog modela i okvira za izradu javnih politika, prilagođenog uslovima u Bosni i Hercegovini. Važna je izgradnja model pristupa izradi prijedloga javnih politika - Policy Model. Osim toga, od velike važnosti je i okvir za izradu javnih politika - Policy Framework, alati za izradu javnih politika - Policy Toolbox te program izrade studentskih prijedloga javnih politika. Program izrade praktičnih prijedloga javnih politika, program izrade interdiciplinarnih javnih politika, program edukacija u oblasti javnih politika, Policy Opservatorij, Policy Implementation Task Force, program za analizu i razvoj tranzicijskih javnih politika te program za usklađivanje domaćih javnih politika sa javnim politikama EU je od velike važnosti.

Generalna hipoteza: "Uspješnim umrežavanjem sa susjednim zemljama članicama Evropske unije nevladine organizacije postaju respektabilan akter u donošenju javnih politika u Bosni i Hercegovini" uspješno je potvrđena na što je potvrdno odgovorilo i 89,5\% ispitanika. Najveći broj ispitanika djelimično se slaže da kada su u pitanju državni akteri odnosno nadležni vladini organi vlasti da iniciraju konkretne aktivnosti donošenja javnih politika u saradnji sa neformalnim donosiocima. Ispitanici su slično odgovorili i kada su u pitanju političari i vladini službenici koji u agendu javnih politika stavljaju one probleme ili pitanja za koja smatraju da trebaju biti prioritet u 
njihovom budućem radu. Najveći broj ispitanika djelimično se slaže kada su u pitanju poslanici u državnom parlamentu, premijeri vlada, ili načelnici općina koji pripremaju prijedloge zakona ili mjera koji doprinose rješavanju određenih društveno-političkih problema građana. Državni službenici u organima javne uprave imaju značajnu ulogu u kreiranju i provođenju javnih politika, mišljenje je najvećeg broja ispitanika kao i da organi uprave kroz kreiranje javnih politika, unapređuju državni pravni okvir. Kako se javne politike usvajaju uz podršku legislativne većine, konsenzusa među direktorima agencija ili na osnovu sudske odluke ispitanici se u potpunosti slažu kao i na pitanje kako nadležni vladini organi vlasti odabiru jednu od više predloženih javnih politika. Najveći broj ispitanika smatra kako nevladine organizacije djeluju institucionalno i neinstitucionalno. Isto su odgovorili i kako kreiranje javnih politika nevladinih organizacija u Bosni i Hercegovini ima praktičnu primjenu u zemljama okruženja i Evropske unije te kao je slabost nevladinih organizacija je međusobni rivalitet.

Značajan je uticaj nevladinih organizacija na zagovaranje i kreiranje javnih politika mišljenje je najvećeg broja ispitanika kao i da rukovodioc nevladine organizacije mora biti stručna i operativna osoba. Ispitanicu su složni kako se povezivanjem sa nevladinim organizacijama zemalja iz okruženja dobija se inozemna potpora i temeljni podsticaj u razvoju. Ispitanici su potvrdno odgovorili kako iniciranje konkretnih aktivnosti i mehanizama zajedničkog djelovanja nevladinih organizacija povećava respektabilnost kod državnih aktera te kako kroz pokretanjem programa za potporu rada nevladinih organizacija dobija se podrška Evropske unije u provedbi zagovaračkih strategija. Finansijska potpora institucija Evropske unije doprinosi jačanju poziciju nevladinih organizacija kod donošenja i implementiranju javnih politika mišljenja je većina ispitanika kao i da se kreiranjem mreža javnih politika od strane motiviranih pojedinaca u nevladinim organizacijama, jačaju se osnove za provedbu zagovaračkih strategija. Ispitanici su složni i kada je u pitanju veliki uticaj na donošenje i realizaciju javne politike od strane javnih aktera vrše interesne skupine (stakeholders), te kako politički akteri temelje svoje razumijevanje legitimiteta nevladinih organizacija na tome da li je neka od njih riješila konkretne probleme. Osim toga, ispitanici se slažu i kada je u pitanju najefikasnije djelovanje nevladinih organizacija se ostvaruje požrtvovanšću i predanošću zaposlenih i volontera te kako nevladine organizacije posjeduju dobru organizaciju rada i prilagodljivost promjenama. Ispitanici se slažu i kako nevladine organizacije inovativnošću u kreiranju programa pridobijaju prepoznatljivost kod građana ali su složni da nevladine organizacije dobrim odnosima sa donatorima kreiraju i dobar imidž u javnosti i široku podršku. Pored toga, složni su i da pozicioniranost i djelovanje poznatih osoba u aktivnostima značajno utiče na promociju nevladinih organizacija te ukoliko određena nevladina organizacija zastupa interese građana to proizilazi iz njenih rezultata koje je u stanju postići. Ispitanici se upotpunosti slažu i kod odgovora da državni akteri vjeruju $\mathrm{u}$ istinske interese $\mathrm{i}$ integritet nevladinih 
organizacija koje se finansiraju iz fondova Evropske unije i drugih donatora ali su složni kako organi javne uprave su skloni da slijede političke vrijednosti iz tradicije. Ispitanici nemaju mišljene ni kada je u pitanju donatorski program nevladinih organizacija ima vrlo dobar politički učinak. Nevladine organizacije zagovaraju međunarodne politike koje se kreiraju na temelju demokratije, civilnog društva i tržišne ekonomije mišljenje je većine ispitanika. Fokus podrške institucija Evropske unije i drugih donatora nevladinim organizacijama te kako vladini akteri nisu sposobni da postanu djelotvorni zagovornici mišljenje je većine ispitanika. Najveći broj ispitanika je kazao da ukoliko institucija Evropske unije pružaju podsticaj za nevladine organizacije, da je to zbog toga što su nevladine organizacije formirane kao reakcija donatorskih finansija. Nevladine organizacije u javnom zagovaranju nisu zadovoljni rezultatima koji nisu implementirani od strane državnih institucija, mišljenje je većine ispitanika. Najveći broj ispitanika potvrdno je odgovorio kako nevladine organizacije mogu da ostvare napredak za civilno društvo ukoliko ulože više napora u zagovaranju javnih politika. Najindikativniji angažman javnog zagovaranja nevladinih organizacija na kreiranje javnih politika u Bosni i Hercegovini moguce je ostvariti putem građanske političke agende (platforme), mišljenje je većine ispitanika. Najveći broj ispitanika je imao od 35 do 43 godine, $60,2 \%$ njih je bilo muškog a $39,8 \%$ ženskog pola, te $76 \%$ sa visokom stručnom spremom.

Za kraj su ispitane hipoteze $\mathrm{H} 0$ sa $\mathrm{H} 1, \mathrm{H} 2$ i $\mathrm{H} 3$ putem testiranja statandardne nezavisnosti dviju kategoričkih varijabli hi-kvadrat u programu SPSS upoređene. U ishodu hi-kvadrat testa vidljiva je nezavisnost zadatih kao i približna dvostrana vjerovatnoća koja je bila .000 iz čega se vidjelo kako su sve zadate varijable $u$ asocijaciji.

\section{Summary}

After the fall of the Berlin Wall in January 1989, the Cold War era ended, as did the dissolution of socialist state communities. The first civil initiatives in SFRY Yugoslavia appeared during the eighties, in Ljubljana in 1983 and in Zagreb in 1989. In the mid-1980s, civic initiatives in Bosnia and Herzegovina also tried to establish a political counterweight, and the Yugoslav Pre-Parliament was especially important, as were other peace groups and initiatives. Bosnia and Herzegovina entered the transition period burdened by the devastation of war and destroyed social infrastructure. The non-governmental sector in Bosnian society significantly influences policy-making. From the collapse of the socialist system, which manifested itself on a symbolic level in the fall

The Berlin Wall and the emergence of civil society organizations and modern NGOs as a significant part of them in Bosnia and Herzegovina, this field is largely unexplored and there is no complex and serious systematic scientific 
analysis of the impact of NGOs on policy making, nor an analysis that deals with the influence of civil society on policy making. After the ban on activities in the socialist environment, traditional cultural and educational societies such as Preporod, Napredak, Prosvjeta, but also the humanitarian societies Merhamet, Caritas, La Benevolencija and others are renewing their work.

The period from the appearance of modern non-governmental organizations until today is quite a sufficient period of time for scientific observation of their influence on the creation of public policies in Bosnia and Herzegovina. Bosnian society to democratic standards in the European Union, then we get an additional motive for researching this phenomenon. The limitations in this complex business were the key terms: public policy and the non-governmental sector, which do not have a long tradition and in Bosnia and Herzegovina are differently interpreted and translated in scientific and professional circles. Within this paper, the development of civil society and non governmental organizations in Bosnia and Herzegovina and their influence on the creation of the entire public policy cycle are analyzed. In that sense, there is a comparative analysis of the development of civil society and non-governmental organizations in the countries around Bosnia and Herzegovina (and the countries of the Western Balkans), as well as mechanisms for influencing the creation of public policies.

The paper aimed to investigate the mechanisms of NGO influence on public policy-making in Bosnia and Herzegovina $(\mathrm{B} \& \mathrm{H})$ after the signing of the Dayton Peace Agreement on 14 December 1995 in Paris. It is important to state how the sudden increase in the number of non-governmental organizations happened immediately after the Dayton Agreement. It is estimated that there were more than 1,500 at the time. However, the Collective Register of Foundations and Associations in Bosnia and Herzegovina contains a total of 25,646 . The number of really active is difficult to determine.

One of the main assumptions in the paper is that by successfully networking with organizations from neighboring EU member states, NGOs become a respectable actor in public policy making in $\mathrm{B} \& \mathrm{H}$. Research within this paper contributes to a better understanding of the role of the non-governmental sector (association) in public advocacy and analysis and comparison of current theories of legal and political framework, structure, size, factors of development of the non-governmental sector. The paper also contributes to the assessment of the current state of the mechanism of influence on the creation of public policy agendas in $\mathrm{B} \& \mathrm{H}$, the formulation of measures for internal structures and networking of NGOs and the definition of their number, structure and types. 


\section{BIBLIOGRAFIJA/BIBLIOGRAPHY}

\section{Knjige/Books:}

1. Beck U, Šta je globalizacija?: zablude globalizma -odgovori na globalizaciju, Vizura, Zagreb 2003.

2. Castles G. G, Komparativne javne politike-primjeri poslijeratne preobrazbe, Masmedija, Zagreb 2009.

3. Đorđević S, Analiza javnih politika, Čigoja, Beograd 2010.

4. Eesley C. \& Lenox, M, "Secondary Stakeholder Actions and the Selection of Firm Targets," Working Paper. Also Best Paper Proceedings of the 2006 Academy of Management Conference. Atlanta, GA, 2006.

5. Gramši A, Izabrana djela, Kultura, Beograd 1959.

6. Jovanović S, Država I, Geca Kon, Beograd 1936.

7. Kin Dž, Civilno društvo, stare slike, nove vizije, Filip Višnjić, Beograd 2003.

8. Kolin M, Nevladine organizacije (pojam, značaj, klasifikacije, profil), u: Petrović B. (ur) Civilno društvo i nevladin sektor, Palgo centar, Beograd 2000.

9. Kuka E, Javne politike, Štamparija Fojnica d.o.o, Sarajevo 2018.

10. Lewis D. (eds). Pluto: Stewart S, Happy ever after in the marketplace: non-government organizations and uncivil society, Review of African Political Economy, London 1997.

11. Lilić S, Upravno pravo, Upravno procesno pravo, Beograd 2008.

12. Maglajlić R.A, Hodžić Edin, "Political Participation." In Democracy Assessment in Bosnia and Herzegovina, ed. Dobrila Govedarica, Open Society Fund Bosnia and Herzegovina, Sarajevo 2006.

13. Mataga Z, Pravno na slobodu udruživanja prema Evropskoj konvenciji za zaštitu ljudskih prava i osnovnih sloboda, Strazbur 2006.

14. Miošić N. ur. et al, Priručnik za analizu javnih politika, EU \& Ured za udruge Republike Hrvatske, Zagreb 2007.

15. Ninković-Papić R. at al, Izvještaj o procjeni socijalnog poduzetništva u Bosni $i$ Hercegovini, FSU u Bosni i Hercegovini, august 2012.

16. Omerefendić S, (ur), Priručnik za nevladine organizacije u Bosni i Hercegovini, EU \& UNDP \& Ministarstvo pravde Bosne i Hercegovine, Sarajevo 2014.

17. Papić Ž. et al, Mit i stvarnostcivilnog društva, FSU u Bosni i Hercegovini, Sarajevo 2011.

18. Pavlović V, Civilno društvo i demokratija, Udruženje za političke nauka Srbije, Beograd 2004.

19. Petrović B. at al, Civilno društvo i nevladin sektor, Magna Agenda, Beograd 2002.

20. Puljek-Shank R, Dead letters on a page? Civic agency and inclusive governance in neopatrimonialism, Radboud Repository of the Radboud University Nijmegen, 2020.

21. Puljek-Shank R, Iznad okvira projekata: lokalni legitimitet $i$ zagovaranje civilnog društva u Bosni i Hercegovini, Friedrich-Ebert-Stiftung, FES, Sarajevo 2020.

22. Sali Terzić S, Civilno društvo, Poglavlje XI u Međunarodne političke podrške zemljama jugoistočne Evrope - Lekcije (ne)naučene u Bosni i Hercegovini, Fond otvoreno društvo ViH, Sarajevo 2001. 
23. Sejfija I, NVO sektor u Bosni i Hercegovini, tranzicijski izazovi, Bosanska riječ, Tuzla 2009.

24. Sejfija I, Povijesne predispozicije $i$ aktuelni razvoj građanskih asocijacija $u$ Bosni i Hercegovini, "Friedrich Ebert Stiftung", Sarajevo 2008.

25. Stojanović Đ, Građansko društvo, Medijska knjižara krug, Beograd 2006.

26. Stubbs P. i Gregson K. (urednici), Social Policy, Protection and Practice: the care of vulnerable groups in Bosnia-Herzegovina, Svijetlost, Sarajevo 1998.

27. Tahirović E, Kuka E, Osnove javnih politika, Fakultet za upravu Univerzitea u Sarajevu 2020.

28. Willetts P, What is a Non-Governmental Organization?. In UNESCO (Eds.), Encyclopedia of Life Support Systems: Encyclopedia of Institutional and Infrastructural Resources, Eolss Publishers, Oxford 2002.

29. Young Eoin i Quinn Lisa, Pisanje djelotvornih prijedloga za javne politike Vodič za policy savjetnike u zemljama Središnje i Jugoistočne Europe, DIM Udruga za građansko obrazovanje i društveni razvoj, Zagreb 2007.

30. Žeravčić G, (ur), Studija mapiranja OCD u Bosni i Hercegovini, European Union \& EPRD, Sarajevo 2016.

\section{Članci/Articles:}

1. Bežovan G, Struktura civilnog društva u Hrvatskoj, Politička misao, vol. XXXIX, br. 1, 2002, 63-87.

2. Ebrahim A, World Development, vol. 31, issue 5, 2003, 813-829

3. Hendry J. R, Taking Aim at Business: What Factors Lead Enviromental Non-Governmental Organizations to Target Particular Firms), Bussiness Society, 45, 2006.

4. Heywood, F. Understanding needs: A starting point for quality, Housing Studies, 19(5), 2004, 709-726.

5. Kendall J, Mohan J, Brookes N, Yoon Y. (2018). The English Voluntary Sector: how Volunteering and Policy Climate Perceptions Matter, Journal of Social Policy, Volume 47 , Issue 4 , Cambridge University Press, 2018.

6. Kidd Q, Civic Participation in America, Springer, New York 2016.

7. Muller Edward N, Seligson Mitchell A, Civic culture and democracy: the question of causal relations, American Political Science Review, vol. 88, no. 3, 1994.

8. Peters G, Pierre J. (ur), Handbook of Public Policy, Sage, London 2004, 461-479.

9. Salamon L. M. et al, Defining the Nonprofit Sector: A Cross - National Analysis, Manchester: Manchester University Press, 2004, 128-168.

10. Teegen $\mathrm{H}$. et al, The importance of nongovernmental organizations (NGOs) in global governance and value creation: An international business research agenda, Journal od International Business Studies, vol. 35, 2004, 463-483.

11. Zhang Ch, Nongovernmental Organizations' Policy Advocacy and Government Responsiveness in China, Journals sagepub, vol 47(2017), Issue 4, 2018. 